\title{
Consequences of Employment Protection? The Case of the Americans with Disabilities Act
}

\author{
Daron Acemoglu and Joshua D. Angrist
}

Massachusetts Institute of Technology

\begin{abstract}
The Americans with Disabilities Act (ADA) requires employers to accommodate disabled workers and outlaws discrimination against the disabled in hiring, firing, and pay. Although the ADA was meant to increase the employment of the disabled, the net theoretical effects are ambiguous. For men of all working ages and women under 40, Current Population Survey data show a sharp drop in the employment of disabled workers after the ADA went into effect. Although the number of disabled individuals receiving disability transfers increased at the same time, the decline in employment of the disabled does not appear to be explained by increasing transfers alone, leaving the ADA as a likely cause. Consistent with this view, the effects of the ADA appear larger in medium-size firms, possibly because small firms were exempt from the ADA. The effects are also larger in states with more ADA-related discrimination charges.
\end{abstract}

\section{Introduction}

Government efforts to eliminate employment and wage discrimination date back to the Equal Pay Act of 1963 and Title VII of the Civil Rights

We thank Lucia Breierova and Chris Mazingo for outstanding research assistance. We also thank two anonymous referees and Patricia Anderson, Peter Diamond, Larry Katz, Alan Krueger, Paul Oyer, James Poterba, Steve Pischke, Robert Topel, and seminar participants at the Bureau of Labor Statistics, the National Bureau of Economic Research Labor Studies Meeting, the 1998 North American meeting of the Econometric Society, Massachusetts Institute of Technology, and University of California, Los Angeles for helpful comments. Special thanks go to Leo Sanchez for help with data from the Equal Employment Opportunity Commission and to Greg Weyland at the Census Bureau for consultations regarding CPS matches and the CPS redesign. The authors bear sole responsibility for the contents of this paper.

[Journal of Political Economy, 2001, vol. 109, no. 5]

(C) 2001 by The University of Chicago. All rights reserved. 0022-3808/2001/10905-0009\$02.50 
Act of 1964, which prohibited discrimination on the basis of race and sex. The most recent pieces of federal antidiscrimination legislation are the Americans with Disabilities Act (ADA) and the Civil Rights Act of 1991 (CRA-91). The ADA requires employers to offer reasonable accommodation to disabled employees and bans discrimination against the disabled in wage determination, hiring, and firing. The ADA seems to be more far-reaching than CRA-91, which essentially modified existing antidiscrimination statutes (see Abram 1993; Oyer and Schaeffer 1998). Proponents of the ADA hope that the act will improve the labor market fortunes of disabled workers by raising the productivity of the disabled and reducing discrimination (see, e.g., Kemp 1991). Critics of the ADA point out that adapting the workplace to the disabled can be expensive and that the costs of accommodation and ADA-related litigation may have significant negative employment effects (e.g., Oi 1991; Rosen 1991; Weaver 1991; Epstein 1992; Olson 1997).

The first objective of this paper is to determine whether the ADA has in fact improved economic conditions for the disabled. A study of the $\mathrm{ADA}$ is also of broader interest, however. Although high-profile reasonable accommodation cases have attracted the most media attention, the majority of ADA charges pertain to wrongful termination. It is therefore possible that the ADA acts as a form of employment protection, similar to European firing costs. Since the ADA primarily affects a specific group, any consequences of employment protection should be easy to detect in this case.

The theory section of the paper uses a standard competitive model to highlight the distinction between accommodation costs and firing and hiring costs due to the threat of lawsuits. Although the ADA's reasonable accommodation provision creates an incentive to employ fewer disabled workers, the introduction of hiring and firing costs complicates the analysis. If the threat of ADA-related litigation encourages employers to increase the hiring of the disabled and if the number of employers is not very responsive to profits or costs, the ADA may increase the employment of disabled workers as ADA proponents had hoped. But when most charges pertain to wrongful termination and costs of reasonable accommodation are high, the ADA is likely to reduce employment of the disabled.

The empirical analysis looks at the employment and wages of disabled and nondisabled workers using data from the March Current Population Survey (CPS) for 1988-97. These data are useful for our purposes because the CPS income supplement identifies disabled workers and the March CPS has information on firm size, a variable that figures in our theoretical discussion and in the ADA's compliance and sanction provisions. To investigate the impact of the ADA on turnover, we constructed measures of separations and accessions by matching CPS rotation 
groups. Finally, we used Equal Employment Opportunity Commission (EEOC) data on discrimination charges by state to connect changes in labor market variables with the incidence of ADA-related charge activity.

The CPS data show a post-ADA decline in the relative employment of disabled men and women aged 21-39, with no change in relative wages. The deterioration in the relative employment position of disabled workers began in 1993 for men and in 1992 for women, the first two years the ADA was in effect. These results are unchanged by controlling for pre-ADA trends in employment of the disabled or for the increase in the fraction of people receiving disability insurance and supplemental security income (SSI). Together these findings lead us to conclude that the ADA reduced employment for disabled workers aged 21-39. The results for those aged $40-58$ are more mixed. There is a post-ADA decline in the employment of disabled men aged 40-58, but no clear evidence of an effect on women aged 40-58.

Additional results suggest that employment of the disabled declined more in medium-size firms, possibly because small firms are exempt from the ADA and large firms can more easily absorb ADA-related costs. Disemployment effects also appear to have been larger in states in which there have been more ADA-related discrimination charges. On the other hand, there is little evidence of a reduction in separation rates of the disabled. This suggests that the negative effects of the ADA may have been due more to the costs of accommodation than to the threat of lawsuits for wrongful termination, though poor measurement of separation rates may also account for this result. Finally, we find no evidence that the ADA had a negative impact on nondisabled workers. This suggests that the adverse consequences of the ADA have been limited to the protected group.

The first papers looking at the effects of the ADA are those by DeLeire $(2000 a, 2000 b)$. Especially relevant is DeLeire $(2000 b)$, which uses the Survey of Income and Program Participation (SIPP) and the Panel Study of Income Dynamics (PSID) to compare labor market outcomes for disabled and nondisabled workers before and after the ADA (through 1995). DeLeire finds large negative effects on employment beginning in 1990, the year the ADA was approved. Our results are similar to those in DeLeire $(2000 b)$ in that we also find a relative decline in employment of the disabled. In other respects, our paper differs from DeLeire's. First, the theoretical discussion emphasizes the employment protection aspect of the ADA, and the empirical results show employment declines only in 1992 or 1993, after the ADA was implemented. Second, matched CPSs are used to assess the importance of composition effects and to look at hiring and firing. Third, we use a number of strategies to control for the expansion of the SSI and disability insurance programs. Finally, 
evidence on employment of the disabled by firm size and state is used to substantiate the main findings.

We begin with the legal background in Section II. Section III presents a theoretical analysis of provisions that protect disabled workers. Section IV describes the data and our empirical strategy. Section V contains the main empirical findings, and Section VI presents conclusions.

\section{Background}

\section{A. ADA Provisions and Coverage}

The ADA was signed into law in July 1990 and came into effect in July 1992. Previously, there was no federal law dealing with the employment and wages of disabled workers in the private sector, although the Rehabilitation Act of 1973 covered disabled workers employed by the federal government or working for federal contractors. A number of states also had laws protecting disabled workers, but the coverage and effectiveness of these laws varied. Title I of the ADA initially covered all employers with at least 25 employees. In 1994, coverage was extended to employers with 15 or more employees. Title I requires employers to provide "reasonable accommodation" for their disabled workers. Examples include enabling wheelchair access, purchasing special equipment for disabled employees, and restructuring jobs to permit disabled employees to work part-time or from home. Title I also bans discrimination against the disabled in wages, hiring, firing, and promotion. For example, a disabled employee should be paid the same amount as a nondisabled worker in the same job, and firms are not allowed to consider disability in hiring and firing decisions. ${ }^{1}$

Enforcement of ADA provisions is left to the EEOC and the courts. Disabled employees or job applicants who believe that they have been discriminated against can file a charge with the EEOC, which will investigate and in some cases try to resolve the charge or sue. If the charge is not resolved and the EEOC does not sue on behalf of the charging party, it issues a letter of permission to sue and the charging party is free to litigate at his or her own expense. The law provides for remedies that include hiring, reinstatement, promotion, back pay, front pay, and reasonable accommodation and for payment of attorney's fees, expert witness fees, and court costs. As a consequence of CRA-91, compensatory and punitive damages are also available if intentional discrimination is found. They range from $\$ 50,000$ for firms with 100 or fewer employees

\footnotetext{
${ }^{1}$ Title II covers discrimination in public programs, and Titles III and IV refer to public accommodations (businesses) and telecommunication. Title $\mathrm{V}$ contains technical information related to enforcement (see Equal Employment Opportunity Commission 1995).
} 
to $\$ 300,000$ for firms with 500 or more employees (Equal Employment Opportunity Commission 1995, p. X-8).

The motivation behind the ADA seems to be that employers incorrectly perceive the disabled to be less productive or are unwilling to make modest adjustments to accommodate them (see, e.g., Kemp 1991). The fact that the labor market fortunes of the disabled are much worse than those of the nondisabled is not in dispute. The disabled earn no more than 40 percent of what nondisabled workers earn. Labor force participation rates of the disabled are much lower, and the disabled are much less likely to be employed (see, e.g., Burkhauser and Daly [1996], Bound and Burkhauser [1999], or our statistics below). Proponents of the ADA believe that the law will induce companies to make the investments and modifications necessary to employ disabled workers and reduce unjustified discrimination. In recent years, interest in the labor market performance of the disabled has also been fueled by efforts to reduce the number of recipients of disability insurance (see, e.g., Leonard 1991).

From July 1992 to September 1997, the EEOC regional offices received 90,803 ADA charges. This figure excludes about 65,000 ADA charges filed with state Fair Employment Practice (FEP) agencies with which the EEOC has work-sharing agreements. ${ }^{2}$ Of the claims filed directly with the EEOC, 29 percent mention "failure to provide accommodation," and 9.4 percent pertained to discrimination at the hiring stage. The majority of charges, 62.9 percent, pertained to wrongful termination (i.e., discharge, failure to rehire, suspension, or layoff). This motivates our interpretation of the ADA as providing a form of employment protection (see also Donahue and Siegelman 1991).

\section{B. How Costly Is the ADA?}

We did not find representative data on the costs of accommodation, though the President's Committee on Employment of People with Disabilities surveyed some employers who contacted them for help in accommodating their disabled workers (Job Accommodation Network 1997). This survey shows an average cost of $\$ 930$ per accommodation since October 1992. This figure is likely to be an underestimate since it includes only voluntary accommodations, and there is no allowance for costs due to time spent dealing with ADA regulations and possible reduced efficiency due to a forced restructuring.

An important component of ADA costs results from litigation. Since

\footnotetext{
${ }^{2}$ These statistics are taken from statistical appendices to EEOC reports and unpublished statistics for recent years provided by the EEOC Office of Communications and Legislative Affairs.
} 
July 1992, over 11,000 of the charges brought directly to EEOC offices under the ADA were resolved by the EEOC, and employers paid over $\$ 174$ million in EEOC-brokered settlements related to these charges. But this figure does not reflect administrative costs, lawyer fees, and private settlements in or out of court. ${ }^{3}$ Although we do not have data on ADA suits alone, Condon and Zolna (1997) reported that employees filed over 40,000 cases each year with state and federal courts, the majority related to discrimination, and won almost 60 percent of the time. They estimated an average award of over $\$ 167,000$ and defense costs of over $\$ 40,000$. These defense costs appear very large, though still less than the $\$ 80,000$ estimated by Dertouzos (1988) for wrongful termination suits in California.

The ADA may also have been a factor in the development of a new insurance market, policies for employment practices liability insurance (EPLI), which covers the costs of employee lawsuits. The EPLI market started in late 1990 and has since grown rapidly, with minimum premiums ranging from $\$ 4,500$ to $\$ 20,000$ a year (Clarke 1996). The growing popularity of EPLI over this period suggests that ADA-related litigation costs are indeed a real concern for employers.

\section{Consequences of Protecting Disabled Workers: Theory}

The theoretical consequences of the $\mathrm{ADA}$ are explored using a standard competitive model with two types of workers, nondisabled and disabled. Some of the points in this section have been made by Oi (1991), Rosen (1991), and Weaver (1991), who informally discuss how the ADA could reduce employment of the disabled by increasing employer costs. The analysis here differs from earlier analyses in a number ways. First, we develop the argument formally and point out the possible general equilibrium interactions. Second, we show that the ADA could increase employment of the disabled because it implicitly subsidizes the hiring of the disabled.

Nondisabled workers supply labor according to the function $n_{a}\left(w_{a}\right)$ and the disabled supply labor according to $n_{d}\left(w_{d}\right)$, where $w_{a}$ is the wage received by nondisabled workers and $w_{d}$ is the wage rate for disabled workers. We assume that $n_{i}$ is increasing in the wage rate for $i=a, d$. All workers are infinitely lived and risk-neutral and have a discount factor $\beta<1$. There are $M$ firms in the labor market that never exit and a large number of potential firms that can enter at cost $\Gamma$. This is a convenient formulation enabling us to discuss both a market characterized by free

\footnotetext{
${ }^{3}$ Costs and settlement data exclude charges filed with state FEP offices. The EEOC annual reports suggest that charges handled by FEP agencies are even more likely to result in an administrative settlement in favor of the charging party (see, e.g., table 5 in the annual report for fiscal year 1994).
} 
entry (when $M \rightarrow 0$ ) and one in which the number of firms is fixed $(M>0$ and $\Gamma \rightarrow \infty)$.

All firms are risk-neutral, discount the future at rate $\beta$, and have access to the production function $F\left(L_{t}, e \cdot D_{t}\right)$, where $L_{t}$ is the number of nondisabled workers, $D_{t}$ is the number of disabled workers employed at time $t$, and $e \leq 1$ measures the relative efficiency of disabled workers. For example, if disabled and nondisabled workers are perfect substitutes so that $F\left(L_{t}, e \cdot D_{t}\right)=f\left(L_{t}+e \cdot D_{t}\right), e<1$ implies that the disabled have a lower marginal product than nondisabled workers. This formulation therefore nests the case in which firms discriminate against the disabled for taste reasons, as in Becker (1971).

We assume that the production function $F$ exhibits decreasing returns to scale. We also assume that with probability $s$ every period, the productivity of a worker at his or her current firm falls to zero, though productivity elsewhere is unaffected (this may be due, e.g., to matchspecific learning as in Jovanovic [1979]). The $L_{t}$ and $D_{t}$ quantities in $F$ include only workers who have not received adverse match-specific shocks.

The issue raised most often in ADA charges is wrongful termination, followed by failure to provide reasonable accommodation and discrimination in hiring. Suppose that disabled job applicants who are not hired sue with probability $p_{d}$ at expected cost $\nu_{d}$, including damages and legal fees. Rejected nondisabled applicants can also sue, falsely claiming to be disabled; this happens with probability $p_{a}$ and has cost $\nu_{a}$. The expected cost of not hiring a disabled worker is therefore $h_{d}=p_{d} \cdot \nu_{d}$, and the corresponding cost for a nondisabled worker is $h_{a}=p_{a} \cdot v_{a}$. We refer to $h_{a}$ and $h_{d}$ as hiring costs, though they are actually costs that the firm incurs when it decides not to hire an applicant. A disabled worker who is fired sues with probability $q_{d}$ for damages $\phi_{d}$. For a nondisabled worker, the corresponding probabilities and damages are $q_{a}$ and $\phi_{a}$, so the expected costs of firing a disabled and a nondisabled worker are $f_{d}=$ $q_{d} \cdot \phi_{d}$ and $f_{a}=q_{a} \cdot \phi_{a}$. We begin with the simple case in which all costs are pure waste, so $h$ and $f$ act like a tax from the point of view of the worker and the firm, though suits may benefit other parties such as lawyers. This seems a reasonable starting place since a significant fraction of the litigation costs imposed on employers probably do not get transferred to disabled workers. Obviously, a fraction of these costs do accrue to workers, giving them a reason to sue, but we defer a discussion of this case.

We assume that $(1-\beta) \cdot f_{a}<w_{a}$ and $(1-\beta) \cdot f_{d}<w_{d}$, so firms always lay off the fraction $s$ of their employees who receive adverse matchspecific shocks. We also assume that there is an excess number of applicants for every job because each worker applies for more than one job. Of the applicants, $D_{F}$ are disabled and $L_{F}$ are nondisabled. We treat 
$D_{F}$ and $L_{F}$ as given. Finally, firms can "accommodate" disabled workers at cost $C$ per worker, for example, by purchasing special equipment. This expenditure increases the marginal productivity of disabled workers by an amount $B$ per worker. ${ }^{4}$ The ADA requires employers to make such accommodations. If $C<B$, employers would make these adjustments voluntarily, even in the absence of the ADA. The fact that government regulation is required suggests that typically $C>B$.

The maximization problem of a firm at time $t=0$ can be written as

$$
\begin{aligned}
\max _{\left\langle D_{t} L_{t}\right\rangle} \Pi \equiv & \sum_{t=0}^{\infty} \beta^{t} \cdot\left(F\left(L_{t}, e \cdot D_{t}\right)-w_{a, t} \cdot L_{t}-w_{d, t} \cdot D_{t}\right. \\
& -c \cdot D_{t}-f_{a} \cdot s \cdot L_{t-1}-f_{d} \cdot s \cdot D_{t-1} \\
& -h_{a} \cdot\left\{L_{F}-\left[L_{t}-(1-s) \cdot L_{t-1}\right]\right\} \\
& \left.-h_{d} \cdot\left\{D_{F}-\left[D_{t}-(1-s) \cdot D_{t-1}\right]\right\}\right),
\end{aligned}
$$

where $L_{-1}=D_{-1}=0, w_{a, t}$ and $w_{d, t}$ denote wages of the nondisabled and disabled at time $t$, and $c=C-B$ is the net cost of accommodation after the ADA. Pre-ADA firing and hiring costs and costs of accommodation are assumed to be zero. The first line of equation (1) is output minus the wage bill. The second line gives accommodation costs and firing costs. Firms discharge a fraction $s$ of their employees who receive an adverse match-specific shock, incurring a firing cost of $f_{d}$ for each disabled layoff and $f_{a}$ for every nondisabled termination. Finally, the third and fourth lines give the "hiring costs" the firm incurs as a function of the number of workers not hired out of the applicant pools, $L_{F}$ and $D_{F}$. When $L_{t}=L_{t-1}$ and $D_{t}=D_{t-1}$ so that employment is not changing, the firm hires $s L_{t-1}$ nondisabled and $s D_{t-1}$ disabled workers to replace those who are laid off. As noted above, $h_{a}$ and $h_{d}$ act as hiring subsidies because the firm reduces its costs by hiring more workers.

Since adjustment costs are linear and there is no aggregate uncertainty, firms immediately adjust to steady-state employment levels, and $w_{a, t}=w_{a}, w_{d, t}=w_{d}, L_{t}=L$, and $D_{t}=D$ in every period $(L$ and $D$ are guaranteed to exist because of the decreasing returns to scale assumption). These equilibrium employment and wage levels satisfy

$$
\begin{aligned}
& \frac{\partial F(L, e \cdot D)}{\partial L}=w_{a}+\beta \cdot s \cdot f_{a}-[1-\beta \cdot(1-s)] \cdot h_{a}, \\
& \frac{\partial F(L, e \cdot D)}{\partial D}=w_{d}+\beta \cdot s \cdot f_{d}-[1-\beta \cdot(1-s)] \cdot h_{d}+c .
\end{aligned}
$$

\footnotetext{
${ }^{4}$ For example, accommodation might increase $e$ from $e_{0}$ to $e_{1}$, in which case $B=$ $\left[F\left(L, e_{1} \cdot D\right)-F\left(L, e_{0} \cdot D\right)\right] / D$.
} 
Both first-order conditions equate the relevant marginal product to the flow marginal cost, inclusive of firing costs, hiring subsidies, and the net costs of accommodation.

To determine equilibrium, we impose market clearing for nondisabled workers:

$$
n_{a}^{-1}(m \cdot L)=w_{a},
$$

where $n_{a}^{-1}$ is the inverse supply function and $m$ is the equilibrium number of firms. The number of firms is determined by

$$
\Pi \leq \Gamma, \quad m \geq M,
$$

which holds with complementary slackness. This means that either the maximized value of profits is equal to entry costs or there is no entry and the number of firms, $m$, is equal to the minimum, $M$.

Finally, the wages received by disabled workers are given by

$$
w_{d}=\max \left\langle n_{d}^{-1}(m \cdot D), \eta \cdot w_{a}\right\rangle,
$$

where $\eta$ is a parameter that equals zero when there are no restrictions on wages of the disabled, so that the disabled are on their labor supply curve. The equal-pay provision sets $\eta=1$ if it is fully enforced. Since employers can pay different wages for different jobs, $\eta \in(0,1)$ seems more likely in practice.

Inspection of the equilibrium conditions yields the following conclusions.

1. From equation (2), it is clearly possible for the ADA to reduce the costs of employing the disabled since $h_{d}$ is a de facto hiring subsidy. The scenario envisaged by ADA proponents can probably be best described as the ADA leading to $h_{d}>0, f_{a}=h_{a}=0, f_{d} \approx 0$, and $c \approx 0$, in which case the ADA can increase employment and wages of the disabled.

2. As we noted in Section II, the ADA appears to have increased $f_{d}$ considerably more than $h_{d}$. Similarly, costs of employing the disabled are increased by the accommodation costs, $c$. Therefore, in practice, the ADA seems most likely to reduce employment and wages of the disabled.

3. The equal-pay provision of the ADA (i.e., $\eta>0$ ) may have increased the wages of the disabled, creating involuntary unemployment off the disabled supply curve. The equal-pay provision also interacts with firing costs and the costs of accommodation by preventing wages from falling to offset these costs, exacerbating the decline in employment of the disabled.

4. Although the partial-equilibrium effect of hiring costs is to increase employment of the disabled, the implicit hiring subsidy $h_{d}$ is effectively financed by reducing profits. If $m>M$ and $\Pi=\Gamma$ to start with, then an increase in $h_{d}$ will cause some firms to shut down, causing employment 
and wages of both the disabled and the nondisabled to fall. More generally, the contrast between the free-entry and fixed-number cases suggests that the ADA will reduce employment most in firms or industries in which profits are close to entry costs. In the empirical work, we use firm size as a proxy for profitability since large firms are typically more profitable (see, e.g., Schmalensee 1989; Scherer and Ross 1990, chap. $11)$.

5. Finally, the ADA could also increase firing and hiring costs for the nondisabled $\left(f_{a}\right.$ and $\left.h_{a}\right)$ since they may now sue claiming to be disabled. This could reduce employment of the nondisabled and also affect employment of the disabled, depending on the elasticity of substitution between the two types of workers.

The discussion so far presumes that $f$ and $h$ act like taxes on the firmworker relationship rather than a transfer from the firm to the worker. We know from the work of Mortensen (1978) and Lazear (1990) that when $f$ and $h$ are pure transfers and side payments are allowed, firing costs should have no effect on employment. To see this in our context, suppose that $f_{a}=h_{a}=h_{d}=0$ and $f_{d}>0$. Under the assumption that $f_{d}$ is a pure transfer and both parties are risk-neutral, the labor supply of disabled workers changes to $n_{d}\left(w_{d}+\beta \cdot s \cdot f_{d}\right)$. The reason for the change is that workers anticipate they may be fired and therefore include the discounted flow value of firing costs, $\beta \cdot s \cdot f_{d}$, in their employment income. It is straightforward to see that as long as $w_{d}$ can fall and keep $w_{d}+\beta \cdot s \cdot f_{d}$ constant, changes in $f_{d}$ have no effect on employment of the disabled. However, the equal-pay provision of the ADA limits this possibility. Moreover, because $f$ and $h$ typically include payments to third parties and because firms and workers are risk-averse, characterizing these costs as a tax on the employment contract seems more realistic.

Finally, we note that the analysis so far ignores the impact of firing costs on separations because separations are exogenous. In a previous version of the paper (details available on request), we allow for timevarying productivity and endogenous separations. This analysis shows that ADA-related firing costs are likely to reduce both hiring and separations.

The theoretical discussion shows that the net effect of the ADA depends on which provisions are most important. Accommodation and firing costs are likely to reduce employment, whereas hiring costs have the opposite effect. If the equal-pay provision is not binding, equilibrium will be on the labor supply curves of disabled and nondisabled workers, and employment declines will be accompanied by declines in wages. More generally, however, the equal-pay provision creates "involuntary unemployment" off the supply curve. The empirical work therefore begins with reduced-form equations of the form 


$$
y_{i t}=x_{i}^{\prime} \cdot \pi_{t}+\delta \cdot d_{i}+\alpha_{t} \cdot d_{i}+\epsilon_{i t},
$$

where $i$ denotes individuals and $t$ time; $y_{i t}$ is weeks worked or average weekly wages; $x_{i}$ is a set of controls with potentially time-varying effects, $\pi_{t}$, including a constant (i.e., a year effect); and $d_{i}$ is a disability main effect, with coefficient $\delta$. The $\alpha_{t}$ coefficients are time-varying disability effects, with the first year normalized to zero. For $t \geq 92, \alpha_{t}$ measures the impact of the ADA on the disabled using the nondisabled as a control group; earlier disability-year interactions provide pretreatment specification checks. Since the ADA potentially affects nondisabled workers as well as the disabled, we also explore empirical specifications that use variation by firm size and state to separately identify effects on the disabled and the nondisabled.

\section{Data and Descriptive Statistics}

The sample is drawn from the 1988-97 March CPS and is limited to those aged 21-58 since this group has strong labor force attachment. Disabled workers are identified in the March CPS income supplement by the following question: "Does [respondent] have a health problem or a disability which prevents him/her from working or which limits the kind or amount of work he/she can do?" This question has been used by other researchers working on disability issues (e.g., Burkhauser, Haveman, and Wolfe 1993; Krueger, Kruse, and Drastal 1995) and is similar to disability questions in the PSID and SIPP (see, e.g., Burkhauser and Daly 1996; Bound and Burkhauser 1999; DeLeire 2000a, 2000b).

The impact of the ADA on employment levels is evaluated by looking at data on weeks worked during the calendar year preceding the March income supplement. The wage measure is average weekly earnings, computed using annual earnings data from the supplement. Although the CPS changed from paper questionnaires to computer-assisted interviewing in 1994 and the main labor force status questions were also revised at that time, the content of the income supplement was not changed. The Appendix discusses matched CPS data for March 1993 and 1994 and provides more information on the CPS redesign and its possible consequences for our analysis.

The variables in the income supplement refer to the previous calendar year, so the sample has data for weeks worked and wages in 1987-96. The disability status question in the supplement appears to refer to respondents' status at the time of the survey (March of the survey year)

\footnotetext{
${ }^{5}$ Using data from the Retirement History Survey and the National Longitudinal Survey of Older Men, Bound (1991) compares objective measures of health status with selfreported measures like the one used here. His results suggest that there is no clear basis for preferring one type of measure over the other.
} 
TABLE 1

Descriptive STATistics

\begin{tabular}{|c|c|c|c|c|c|c|c|c|c|c|}
\hline & \multicolumn{2}{|r|}{1988} & \multicolumn{2}{|r|}{1990} & \multicolumn{2}{|r|}{1992} & \multicolumn{2}{|r|}{1994} & \multicolumn{2}{|c|}{1996} \\
\hline & $\begin{array}{l}\text { Disabled } \\
\text { (1) }\end{array}$ & $\begin{array}{c}\text { Nondisabled } \\
\text { (2) }\end{array}$ & $\begin{array}{l}\text { Disabled } \\
\text { (3) }\end{array}$ & $\begin{array}{c}\text { Nondisabled } \\
\text { (4) }\end{array}$ & $\begin{array}{l}\text { Disabled } \\
(5)\end{array}$ & $\begin{array}{c}\text { Nondisabled } \\
(6)\end{array}$ & $\begin{array}{l}\text { Disabled } \\
\quad(7)\end{array}$ & $\begin{array}{c}\text { Nondisabled } \\
\text { (8) }\end{array}$ & $\begin{array}{l}\text { Disabled } \\
(9)\end{array}$ & $\begin{array}{c}\text { Nondisabled } \\
(10)\end{array}$ \\
\hline & \multicolumn{10}{|c|}{ A. Men Aged 21-39 } \\
\hline Age & 31.1 & 29.9 & 31.2 & 30.0 & 31.4 & 30.1 & 31.5 & 30.3 & 32.0 & 30.4 \\
\hline White & .82 & .86 & .79 & .84 & .77 & .84 & .76 & .83 & .75 & .83 \\
\hline Post-high school & .27 & .48 & .27 & .47 & .26 & .50 & .28 & .53 & .33 & .53 \\
\hline Working & .42 & .88 & .44 & .89 & .39 & .86 & .35 & .87 & .35 & .88 \\
\hline Weeks worked & 20.4 & 45.1 & 22.8 & 45.6 & 18.8 & 44.1 & 17.8 & 44.2 & 17.4 & 45.1 \\
\hline Weekly wage & 358.0 & 446.9 & 317.5 & 436.9 & 329.7 & 421.2 & 324.7 & 426.6 & 294.1 & 421.5 \\
\hline SSI or DI & .29 & .004 & .27 & .003 & .32 & .01 & .32 & .003 & .37 & .004 \\
\hline \multirow[t]{2}{*}{ Observations } & 1,059 & 21,532 & 996 & 21,853 & 1,063 & 21,254 & 1,050 & 19,683 & 770 & 16,492 \\
\hline & \multicolumn{10}{|c|}{ B. Women Aged 21-39 } \\
\hline Age & 30.8 & 29.9 & 31.3 & 30.0 & 31.2 & 30.2 & 32.1 & 30.3 & 31.9 & 30.4 \\
\hline White & .77 & .83 & .80 & .82 & .79 & .82 & .77 & .81 & .76 & .81 \\
\hline Post-high school & .25 & .46 & .28 & .47 & .32 & .52 & .35 & .56 & .39 & .57 \\
\hline Working & .37 & .70 & .38 & .71 & .34 & .70 & .27 & .71 & .30 & .72 \\
\hline Weeks worked & 17.7 & 34.6 & 19.8 & 35.0 & 18.8 & 35.1 & 14.2 & 35.1 & 16.1 & 35.9 \\
\hline Weekly wage & 234.3 & 295.5 & 243.5 & 298.2 & 253.2 & 297.8 & 240.1 & 303.5 & 250.5 & 304.0 \\
\hline SSI or DI & .25 & .01 & .23 & .01 & .26 & .01 & .32 & .02 & .32 & .02 \\
\hline Observations & 932 & 23,967 & 927 & 24,022 & 963 & 23,445 & 995 & 21,761 & 881 & 18,262 \\
\hline
\end{tabular}


C. Men Aged 40-58

\begin{tabular}{|c|c|c|c|c|c|c|c|c|c|c|}
\hline Age & 49.7 & 47.9 & 49.3 & 47.6 & 48.9 & 47.6 & 49.3 & 47.6 & 49.0 & 47.6 \\
\hline White & .79 & .88 & .82 & .87 & .83 & .87 & .81 & .86 & .80 & .86 \\
\hline Post-high school & .25 & .45 & .23 & .49 & .29 & .55 & .32 & .58 & .34 & .57 \\
\hline Working & .34 & .92 & .31 & .93 & .31 & .90 & .26 & .91 & .27 & .91 \\
\hline Weeks worked & 16.4 & 47.5 & 16.2 & 47.9 & 16.0 & 46.9 & 13.6 & 46.9 & 14.3 & 47.2 \\
\hline Weekly wage & 461.3 & 636.7 & 408.8 & 626.8 & 401.7 & 612.1 & 424.6 & 619.9 & 422.4 & 586.1 \\
\hline SSI or DI & .33 & .01 & .33 & .01 & .35 & .01 & .39 & .01 & $\begin{array}{r}\text { T2L.T } \\
.40\end{array}$ & .01 \\
\hline Observations & 1,387 & 13,743 & 1,491 & 14,133 & 1,533 & 14,558 & 1,579 & 14,267 & 1,429 & 13,109 \\
\hline & & & & & D. Wome & ged 40- & & & & \\
\hline Age & 50.2 & 47.9 & 49.9 & 47.7 & 49.3 & 47.6 & 49.5 & 47.6 & 49.3 & 47.7 \\
\hline White & .78 & .86 & .79 & .86 & .79 & .85 & .76 & .85 & .77 & .85 \\
\hline Post-high school & .20 & .36 & .19 & .39 & .27 & .47 & .28 & .51 & .30 & .53 \\
\hline Working & .23 & .70 & .23 & .73 & .22 & .74 & .24 & .76 & .23 & .78 \\
\hline Weeks worked & 11.2 & 35.1 & 11.7 & 36.5 & 11.6 & 37.3 & 13.3 & 37.9 & 11.3 & 38.9 \\
\hline Weekly wage & 231.1 & 333.1 & 246.7 & 344.7 & 245.8 & 354.4 & 278.8 & 364.7 & 257.3 & 369.9 \\
\hline SSI or DI & .27 & .01 & .27 & .01 & .31 & .01 & .33 & .02 & .35 & .02 \\
\hline Observations & 1,384 & 14,726 & 1,518 & 15,345 & 1,579 & 15,564 & 1,699 & 15,665 & 1,650 & 14,026 \\
\hline
\end{tabular}




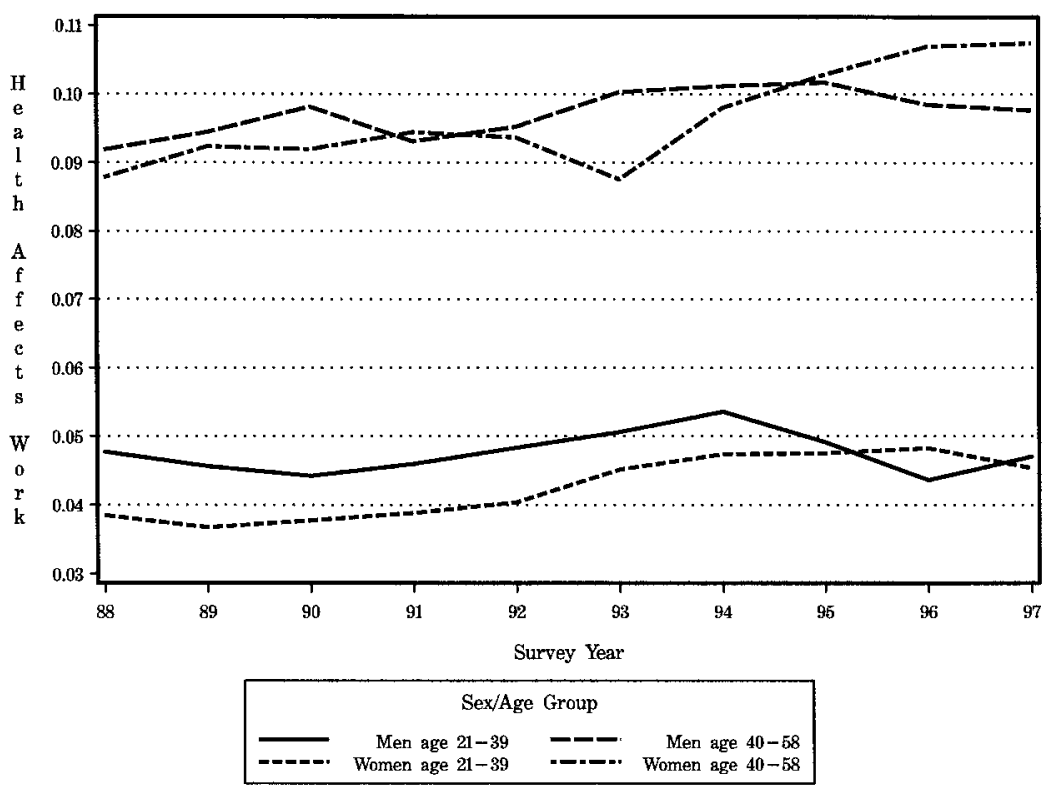

FIG. 1.-Work-related disability rates for men and women aged 21-58 in the 1988-67 March CPS.

but actually serves as a lead-in question prefacing additional supplement questions about disability income in the previous year. Except for table 1 and figures 1, 4, and 5, which present statistics dated by survey year, the tables and figures refer to estimates by year of observation, which is the survey year minus one.

Descriptive statistics organized by survey year, age group, sex, and disability status are reported in table 1 . The table shows that even in the narrow age and sex groups in our subsamples, there are marked differences between the disabled and nondisabled. The disabled are older, less likely to be white, and less educated, as in the statistics reported by Burkhauser et al. (1993, table 4) from the 1983 and 1987 CPS. The disabled are also much less likely to be employed. For example, while nondisabled men aged 21-58 work over 45 weeks a year on average, disabled men work fewer than 20 weeks, on average, and are paid considerably lower wages when employed.

Figure 1 documents the evolution of work-related disability rates. Disability rates for men aged 40-58 started increasing in 1991, with a slight decline in 1996 and 1997. Disability rates for women aged 40-58 increased sharply starting in 1994. For men aged 21-39, there was a small 
increase in self-reported disability rates between 1990 and 1994, which was later reversed. In fact, in 1996 the disability rate for this group is lower than it was in 1990. These patterns suggest that the ADA may have had an effect on the probability that individuals, especially women, describe themselves as disabled. ${ }^{6}$ This in turn raises the possibility of composition effects, a point we return to in the discussion of results.

\section{Results}

A. Employment and Wage Effects

Figure 2 plots average weeks worked by age group. Weeks worked by disabled men aged 21-39 (fig. 2a) dropped sharply between 1992 and 1993, and those by disabled women aged 21-39 started falling in 1992. Weeks worked by men aged 40-58 (fig. 2b) also show a marked decline between 1992 and 1993. In contrast, there was an increase in weeks worked by disabled women aged 40-58 between 1992 and 1993 .

Table 2 reports ordinary least squares (OLS) estimates of equation (6). The dependent variables are weeks worked and log weekly earnings. The controls in these regressions are dummies for individual disability status, year, two 10-year age groups, three schooling groups, three race groups, and nine census region main effects, plus interaction terms for age $\times$ year, schooling $\times$ year, race $\times$ year, and region $\times$ year. The coefficients of interest are a full set of year $\times$ disability interactions, with 1987 as the base period. These year $\times$ disability interaction terms, that is, the $\alpha$ 's in equation (6), describe the change in relative employment of the disabled. We think of 1993-96 as posttreatment years, whereas 1992 is a transition year during which the ADA was only partially in effect. The pre-1992 years provide "pretreatment" specification tests, though they could also capture possible anticipation effects of the ADA. The table also reports estimates from specifications including a linear time trend interacted with disability status. This allows for the possibility that changes in outcomes by disability status can be explained by extrapolating different trends for the disabled and nondisabled. The linear trend specification cannot be estimated with a full set of disability $\times$ year interactions, so the trend specification includes interactions for 1991-96 only.

The results in table 2 suggest a substantial and statistically significant decline in weeks worked by disabled people under 40 after the ADA became effective, with little evidence of a preexisting trend or antici-

\footnotetext{
${ }^{6}$ The fact that the disabled may be an elastic population has been noted by Oi (1991), Bound and Waidmann (1992), and Kubik (1997). On the other hand, Dwyer and Mitchell (1998) argue that disability status does not appear to be endogenous in models of retirement behavior.
} 
a

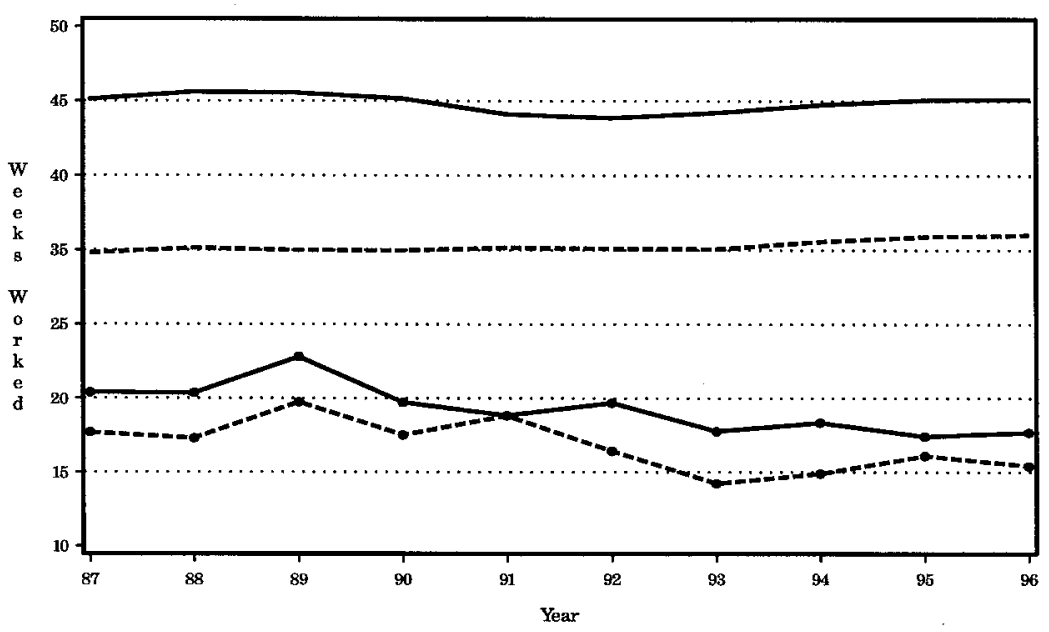

b

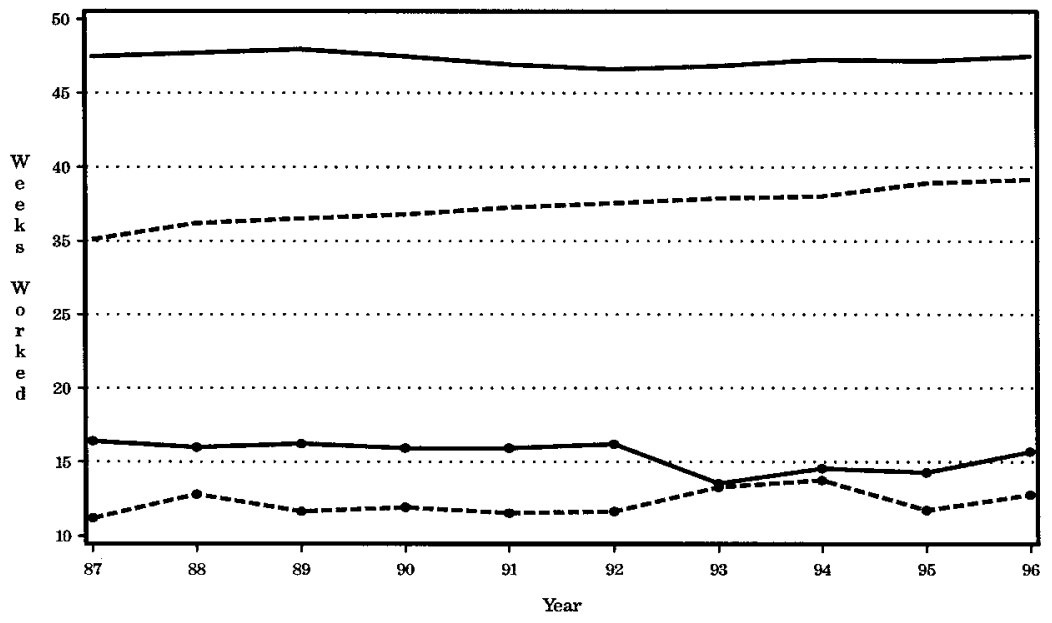

\begin{tabular}{|lll|}
\hline-1 nondisabled men & disabled men \\
nondisabled women
\end{tabular}

FIG. 2.-Weeks worked last year by sex and disability status. $a$, CPS respondents aged 21-39. $b$, CPS respondents aged 40-58. 
TABLE 2

INITIAL RESULTS

\begin{tabular}{|c|c|c|c|c|c|c|c|c|}
\hline \multirow[b]{3}{*}{ EFFECT } & \multicolumn{4}{|c|}{ Dependent Variable: Weeks Worked } & \multicolumn{4}{|c|}{$\begin{array}{c}\text { DePENDENT Variable: LOG OF WeEkLY } \\
\text { EARNINGS }\end{array}$} \\
\hline & \multicolumn{2}{|c|}{ Men } & \multicolumn{2}{|c|}{ Women } & \multicolumn{2}{|c|}{ Men } & \multicolumn{2}{|c|}{ Women } \\
\hline & (1) & (2) & (3) & $(4)$ & $(5)$ & (6) & $(7)$ & $(8)$ \\
\hline & \multicolumn{8}{|c|}{ A. Age 21-39 } \\
\hline Disability $\times 1988$ & $\begin{array}{l}-.41 \\
(.71)\end{array}$ & & $\begin{array}{c}-1.08 \\
(1.07)\end{array}$ & & $\begin{array}{c}-.052 \\
(.044)\end{array}$ & & $\begin{array}{c}-.055 \\
(.052)\end{array}$ & \\
\hline Disability $\times 1989$ & $\begin{array}{l}2.00 \\
(.71)\end{array}$ & & $\begin{array}{c}.67 \\
(1.06)\end{array}$ & & $\begin{array}{c}-.062 \\
(.043)\end{array}$ & & $\begin{array}{l}.050 \\
(.050)\end{array}$ & \\
\hline Disability $\times 1990$ & $\begin{array}{l}-.79 \\
(.71)\end{array}$ & & $\begin{array}{l}-1.33 \\
(1.05)\end{array}$ & & $\begin{array}{l}-.035 \\
(.044)\end{array}$ & & $\begin{array}{r}-.111 \\
(.050)\end{array}$ & \\
\hline Disability $\times 1991$ & $\begin{array}{l}-.53 \\
(.70)\end{array}$ & $\begin{array}{l}-.70 \\
(.78)\end{array}$ & $\begin{array}{c}.08 \\
(1.04)\end{array}$ & $\begin{array}{c}1.09 \\
(1.16)\end{array}$ & $\begin{array}{c}-.020 \\
(.043)\end{array}$ & $\begin{array}{l}.046 \\
(.049)\end{array}$ & $\begin{array}{l}.105 \\
(.050)\end{array}$ & $\begin{array}{l}.191 \\
(.055)\end{array}$ \\
\hline Disability $\times 1992$ & $\begin{array}{l}.57 \\
(.69)\end{array}$ & $\begin{array}{l}.40 \\
(.95)\end{array}$ & $\begin{array}{c}-2.81 \\
(1.02)\end{array}$ & $\begin{array}{c}-1.56 \\
(1.40)\end{array}$ & $\begin{array}{l}-.00 \\
(.043)\end{array}$ & $\begin{array}{l}.078 \\
(.059)\end{array}$ & $\begin{array}{c}-.010 \\
(.050)\end{array}$ & $\begin{array}{l}.100 \\
(.067)\end{array}$ \\
\hline Disability $\times 1993$ & $\begin{array}{c}-1.44 \\
(.69)\end{array}$ & $\begin{array}{c}-1.61 \\
(1.14)\end{array}$ & $\begin{array}{c}-4.37 \\
(1.02)\end{array}$ & $\begin{array}{r}-2.89 \\
(1.69)\end{array}$ & $\begin{array}{l}-.04 \\
(.044)\end{array}$ & $\begin{array}{l}.050 \\
(.072)\end{array}$ & $\begin{array}{c}-.058 \\
(.050)\end{array}$ & $\begin{array}{l}.074 \\
(.082)\end{array}$ \\
\hline Disability $\times 1994$ & $\begin{array}{r}-1.63 \\
(.70)\end{array}$ & $\begin{array}{c}-1.80 \\
(1.35)\end{array}$ & $\begin{array}{c}-5.00 \\
(1.01)\end{array}$ & $\begin{array}{c}-3.29 \\
(1.98)\end{array}$ & $\begin{array}{c}-.143 \\
(.044)\end{array}$ & $\begin{array}{c}-.042 \\
(.084)\end{array}$ & $\begin{array}{c}-.043 \\
(.050)\end{array}$ & $\begin{array}{l}.112 \\
(.095)\end{array}$ \\
\hline Disability $\times 1995$ & $\begin{array}{r}-2.93 \\
(.72)\end{array}$ & $\begin{array}{c}-3.09 \\
(1.56)\end{array}$ & $\begin{array}{r}-3.93 \\
(1.01)\end{array}$ & $\begin{array}{r}-1.99 \\
(2.29)\end{array}$ & $\begin{array}{r}-.098 \\
(.046)\end{array}$ & $\begin{array}{l}.014 \\
(.098)\end{array}$ & $\begin{array}{l}.005 \\
(.049)\end{array}$ & $\begin{array}{l}.184 \\
(.110)\end{array}$ \\
\hline Disability $\times 1996$ & $\begin{array}{r}-2.68 \\
(.70)\end{array}$ & $\begin{array}{c}-2.84 \\
(1.77)\end{array}$ & $\begin{array}{c}-4.41 \\
(1.03)\end{array}$ & $\begin{array}{c}-2.23 \\
(2.62)\end{array}$ & $\begin{array}{r}-.158 \\
(.044)\end{array}$ & $\begin{array}{c}-.034 \\
(.110)\end{array}$ & $\begin{array}{c}-.111 \\
(.050)\end{array}$ & $\begin{array}{l}.090 \\
(.125)\end{array}$ \\
\hline $\begin{array}{l}\text { Disability } \times \\
\text { linear trend }\end{array}$ & & $\begin{array}{c}-.004 \\
(.22)\end{array}$ & & $\begin{array}{r}-.23 \\
(.33)\end{array}$ & & $\begin{array}{c}-.012 \\
(.014)\end{array}$ & & $\begin{array}{r}-.023 \\
(.016)\end{array}$ \\
\hline \multirow[t]{2}{*}{ Observations } & 193,317 & 193,317 & 211,910 & 211,910 & 167,974 & 167,974 & 157,688 & 157,688 \\
\hline & \multicolumn{8}{|c|}{ B. Age $40-58$} \\
\hline Disability $\times 1988$ & $\begin{array}{l}-.49 \\
(.55)\end{array}$ & & $\begin{array}{c}.29 \\
(.88)\end{array}$ & & $\begin{array}{c}-.020 \\
(.044)\end{array}$ & & $\begin{array}{l}.111 \\
(.053)\end{array}$ & \\
\hline Disability $\times 1989$ & $\begin{array}{c}-.47 \\
(.58)\end{array}$ & & $\begin{array}{c}-.94 \\
(.88)\end{array}$ & & $\begin{array}{c}-.109 \\
(.043)\end{array}$ & & $\begin{array}{l}.039 \\
(.053)\end{array}$ & \\
\hline Disability $\times 1990$ & $\begin{array}{l}-.22 \\
(.58)\end{array}$ & & $\begin{array}{r}-1.52 \\
(.87)\end{array}$ & & $\begin{array}{r}-.064 \\
(.044)\end{array}$ & & $\begin{array}{l}.130 \\
(.053)\end{array}$ & \\
\hline Disability $\times 1991$ & $\begin{array}{l}.34 \\
(.57)\end{array}$ & $\begin{array}{l}.79 \\
(.63)\end{array}$ & $\begin{array}{r}-1.91 \\
\quad(.86)\end{array}$ & $\begin{array}{l}.09 \\
(.94)\end{array}$ & $\begin{array}{c}-.109 \\
(.043)\end{array}$ & $\begin{array}{l}.011 \\
(.048)\end{array}$ & $\begin{array}{c}-.012 \\
(.052)\end{array}$ & $\begin{array}{r}-.161 \\
(.056)\end{array}$ \\
\hline Disability $\times 1992$ & $\begin{array}{l}.77 \\
(.56)\end{array}$ & $\begin{array}{l}1.28 \\
(.76)\end{array}$ & $\begin{array}{c}-2.24 \\
(.87)\end{array}$ & $\begin{array}{c}.36 \\
(1.15)\end{array}$ & $\begin{array}{c}-.191 \\
(.042)\end{array}$ & $\begin{array}{c}-.043 \\
(.058)\end{array}$ & $\begin{array}{l}.065 \\
(.053)\end{array}$ & $\begin{array}{c}-.115 \\
(.070)\end{array}$ \\
\hline Disability $\times 1993$ & $\begin{array}{c}-2.12 \\
(.56)\end{array}$ & $\begin{array}{c}-1.55 \\
(.92)\end{array}$ & $\begin{array}{c}-.92 \\
(.85)\end{array}$ & $\begin{array}{c}2.26 \\
(1.38)\end{array}$ & $\begin{array}{c}-.068 \\
(.042)\end{array}$ & $\begin{array}{l}.108 \\
(.070)\end{array}$ & $\begin{array}{l}.098 \\
(.051)\end{array}$ & $\begin{array}{c}-.113 \\
(.082)\end{array}$ \\
\hline Disability $\times 1994$ & $\begin{array}{r}-1.57 \\
(.55)\end{array}$ & $\begin{array}{l}-.94 \\
(1.08)\end{array}$ & $\begin{array}{r}-1.24 \\
(.83)\end{array}$ & $\begin{array}{c}2.53 \\
(1.61)\end{array}$ & $\begin{array}{l}-.10 \\
(.042)\end{array}$ & $\begin{array}{l}.105 \\
(.082)\end{array}$ & $\begin{array}{l}.007 \\
(.051)\end{array}$ & $\begin{array}{c}-.235 \\
(.096)\end{array}$ \\
\hline Disability $\times 1995$ & $\begin{array}{r}-1.83 \\
(.55)\end{array}$ & $\begin{array}{c}-1.14 \\
(1.25)\end{array}$ & $\begin{array}{r}-3.68 \\
(.82)\end{array}$ & $\begin{array}{c}.68 \\
(1.86)\end{array}$ & $\begin{array}{l}-.10 \\
(.042)\end{array}$ & $\begin{array}{l}.133 \\
(.095)\end{array}$ & $\begin{array}{c}-.027 \\
(.049)\end{array}$ & $\begin{array}{c}-.300 \\
(.112)\end{array}$ \\
\hline Disability $\times 1996$ & $\begin{array}{c}-.75 \\
(.55)\end{array}$ & $\begin{array}{l}-.001 \\
(1.42)\end{array}$ & $\begin{array}{r}-3.39 \\
(.81)\end{array}$ & $\begin{array}{c}1.56 \\
(2.12)\end{array}$ & $\begin{array}{c}-.064 \\
(.041)\end{array}$ & $\begin{array}{l}.197 \\
(.108)\end{array}$ & $\begin{array}{c}-.096 \\
(.048)\end{array}$ & $\begin{array}{c}-.400 \\
(.128)\end{array}$ \\
\hline $\begin{array}{l}\text { Disability } \times \\
\text { linear trend }\end{array}$ & & $\begin{array}{l}-.06 \\
(.18)\end{array}$ & & $\begin{array}{l}-.59 \\
(.27)\end{array}$ & & $\begin{array}{c}-.028 \\
(.014)\end{array}$ & & $\begin{array}{l}.031 \\
(.018)\end{array}$ \\
\hline Observations & 146,309 & 146,309 & 157,589 & 157,589 & 116,665 & 116,665 & 109,082 & 109,082 \\
\hline
\end{tabular}

NOTE-Standard errors are reported in parentheses. The table reports year $\times$ disability interactions in regressions that include disability, year, year $\times$ age, year $\times$ race, year $\times$ schooling, and year $\times$ region dummies. 
pation effects. For example, column 1 of panel A shows that weeks worked by disabled men aged 21-39 were stable until 1992 but fell by 1.4 weeks in 1993 and declined by an additional week and a half between 1993 and 1995. Column 2 shows that controlling for disability-specific trends does not change these results, and as suggested by the pre-1993 disability $\times$ year interactions, the linear trend is small and insignificant.

Results for women aged 21-39 are similar to those for men (see cols. 3 and 4), but the decline in employment of the disabled starts in 1992 with a statistically significant drop of 2.8 weeks. This is followed by larger drops in 1993 and 1994, with a slight recovery in the next three years. Estimates from the model with a linear trend in column 4 are similar, and the trend coefficient is again insignificant, though somewhat larger than for men. The lack of any decline in employment of the disabled before 1992 for both groups, and the subsequent sharp employment declines in 1992 and 1993, suggest that the ADA did not change employers' behavior before the law became effective. This seems reasonable since the consequences of the ADA for employers were not clear before its enforcement (see, e.g., Veres and Sims 1995). ${ }^{7}$

Panel B reports estimates for the 40-58 age group. The disability $\times$ year interactions for men are close to zero before 1993 and equal to -2.1 weeks in 1993 . The estimate from the model with a disabilityspecific trend is similar but somewhat smaller at 1.6 weeks. With or without a trend, the effects are substantially weaker by 1996 .

Finally, column 3 shows a decline in the relative employment of disabled women aged 40-58 starting as early as 1990, before the ADA came into effect. These effects disappear once we control for disability-specific trends, and, in fact, the coefficients of interest, reported in column 4, change sign. So there is little evidence that the ADA had an effect on the employment of disabled women in the 40-58 age group. We return to this issue in Section VI.

Columns 5-8 in panel A report estimates for the log weekly earnings of men and women aged 21-39, and panel B pertains to the older age group. There is an effect on men of all age groups in 1994, 1995, and 1996, but these effects disappear in models with a trend. There is much less evidence of a wage effect for women aged 21-39 and once again no evidence of an effect in models that include a trend. On balance, there is little clear evidence for a post-ADA change in the relative wages of disabled workers. The rest of the paper therefore focuses on a further investigation of the employment effects, and the analysis is limited to

\footnotetext{
${ }^{7}$ It is also noteworthy that the effects in 1992 and 1993 coincide with the beginning of a cyclical recovery, which ordinarily benefits the disabled (see, e.g., Yelin and Katz 1994; Bound and Burkhauser 1999).
} 
TABLE 3

Baseline and Alternative Estimates

\begin{tabular}{|c|c|c|c|c|}
\hline & $\begin{array}{l}\text { Baseline } \\
\text { (1) }\end{array}$ & $\begin{array}{l}\text { No Control } \\
\text { (2) }\end{array}$ & $\begin{array}{c}\text { Regression } \\
\text { Control } \\
(3)\end{array}$ & $\begin{array}{l}\text { Semiparametric } \\
\text { Differences-in- } \\
\text { Differences } \\
\text { (4) }\end{array}$ \\
\hline & \multicolumn{4}{|c|}{ A. Men Aged 21-39 $(N=193,317)$} \\
\hline Disability main effect & $-23.8(.25)$ & $-24.5(.26)$ & $-17.3(.89)$ & $-23.6(.28)$ \\
\hline Disability $\times 1991$ & $-.71(.55)$ & $-.72(.56)$ & $-.60(.55)$ & $-1.16(.63)$ \\
\hline Disability $\times 1992$ & $.38(.54)$ & $.38(.55)$ & $.08(.54)$ & $.34(.64)$ \\
\hline Disability $\times 1993$ & $-1.63(.54)$ & $-1.91(.55)$ & $-1.39(.53)$ & $-1.49(.62)$ \\
\hline Disability $\times 1994$ & $-1.82(.55)$ & $-1.85(.56)$ & $-1.72(.55)$ & $-.96(.65)$ \\
\hline Disability $\times 1995$ & $-3.11(.58)$ & $-3.10(.59)$ & $-2.97(.57)$ & $-3.44(.69)$ \\
\hline \multirow[t]{2}{*}{ Disability $\times 1996$} & $-2.87(.56)$ & $-2.89(.57)$ & $-2.68(.56)$ & $-3.30(.64)$ \\
\hline & \multicolumn{4}{|c|}{ B. Women Aged 21-39 $(N=211,910)$} \\
\hline Disability main effect & $-14.0(.38)$ & $-16.8(.39)$ & $-12.9(1.3)$ & $-14.2(.40)$ \\
\hline Disability $\times 1991$ & $.51(.81)$ & $.50(.84)$ & $.31(.81)$ & $.31(1.03)$ \\
\hline Disability $\times 1992$ & $-2.37(.78)$ & $-1.84(.81)$ & $-2.29(.78)$ & $-2.36(.91)$ \\
\hline Disability $\times 1993$ & $-3.93(.78)$ & $-4.00(.80)$ & $-3.73(.78)$ & $-3.36(.93)$ \\
\hline Disability $\times 1994$ & $-4.57(.77)$ & $-3.83(.79)$ & $-4.26(.77)$ & $-4.19(.89)$ \\
\hline Disability $\times 1995$ & $-3.50(.77)$ & $-2.98(.79)$ & $-3.33(.77)$ & $-3.46(.97)$ \\
\hline \multirow[t]{2}{*}{ Disability $\times 1996$} & $-3.98(.79)$ & $-3.98(.81)$ & $-3.75(.80)$ & $-3.53(.93)$ \\
\hline & \multicolumn{4}{|c|}{ C. Men Aged 40-58 $(N=146,309)$} \\
\hline Disability main effect & $-29.7(.20)$ & $-31.5(.20)$ & $-24.7(.74)$ & $-30.0(.24)$ \\
\hline Disability $\times 1991$ & $.64(.44)$ & $.52(.44)$ & $.25(.44)$ & $.48(.54)$ \\
\hline Disability $\times 1992$ & $1.07(.42)$ & $1.09(.42)$ & $.33(.42)$ & $.43(.55)$ \\
\hline Disability $\times 1993$ & $-1.82(.42)$ & $-1.78(.42)$ & $-2.40(.42)$ & $-2.09(.53)$ \\
\hline Disability $\times 1994$ & $-1.27(.41)$ & $-1.19(.41)$ & $-1.96(.41)$ & $-1.38(.54)$ \\
\hline Disability $\times 1995$ & $-1.53(.41)$ & $-1.36(.41)$ & $-2.25(.41)$ & $-2.08(.55)$ \\
\hline Disability $\times 1996$ & $-.45(.40)$ & $-.28(.41)$ & $-1.29(.41)$ & $-1.18(.55)$ \\
\hline
\end{tabular}

NoTE. -Standard errors are reported in parentheses. The dependent variable is weeks worked. All regressions include year and disability main effects. The regression estimates include controls for a full set of year $\times$ covariate effects and disability $\times$ covariate effects. Col. 4 reports the weighted average of differences-in-differences estimates computed separately for every covariate cell. Covariates are age (two 10-year groups), race (white, black, other), schooling (less than high school, high school graduate, some college), and nine census regions for 162 possible cells in each sex/age subsample. The weights are given by the distribution of cells among the disabled in 1988-91.

the demographic groups for which the evidence for employment effects is strongest-women aged 21-39 and men in both age groups.

\section{Alternative Specifications}

Disabled and nondisabled workers have different demographic characteristics, so comparisons by disability status should control for differences in employment trends due to personal characteristics. Table 3 explores the role of individual characteristics by comparing estimates from regressions with no controls other than disability and year main effects to estimates from models with a rich set of controls and interactions between these controls and disability status. To save space, we report results from a parsimonious specification that includes disability $\times$ year interactions for post- 1990 years only.

The estimates in column 1 of table 3 (in all three panels) are taken 
from our baseline specification. This is the same as the model reported in table 2, except that the pre-1991 interaction terms are dropped. The results are similar to those in table 2 . The first variation on this specification, with results reported in column 2, drops all demographic controls. The results are remarkably insensitive to this change.

The next specification consists of a regression model in which the effect of all covariates varies nonparametrically by year and by disability status. In particular, we estimated

$$
y_{i t}=\pi_{t x}+\delta_{d x}+\alpha_{t} \cdot d_{i}+\eta_{i t}
$$

where $y_{i t}$ is weeks worked, $\pi_{t x}$ is a year-specific covariate effect, and $\delta_{d x}$ is a disability-specific covariate effect. As before, the $\alpha_{t}$ coefficients are time-varying disability effects, though we now normalize the disability interactions to zero for $t=87,88,89$, and 90 .

Equation (7) can be thought of as allowing a separate main effect for each covariate cell, with the restriction that the year $\times$ disability interactions are the same in each covariate cell. An even more flexible approach is to estimate the model cell by cell, allowing the main effects and the year $\times$ disability interactions to differ by cell, and then compute the average interaction term using the distribution of cell characteristics among the disabled. That is, separately, for each of 162 cells defined by the covariates, $x$, we estimated

$$
y_{i t}=\pi_{t x}+\delta_{d x}+\alpha_{t x} \cdot d_{i}+\xi_{i t}
$$

The "semiparametric differences-in-differences estimates," reported in column 4 of table 3 , are computed as $\hat{\alpha}_{t}=\sum_{x} \omega_{x} \cdot \alpha_{t x}$, where $\omega_{x}$ is the fraction of the disabled with characteristics $x$ in the (pre-ADA) 1988-91 CPS. In other words, $\hat{\alpha}_{t}$ estimates the expected covariate-specific differences-in-differences parameter using the distribution of $x$ among the disabled. ${ }^{8}$

Although regression and semiparametric control schemes change the size of the disability main effects, the year $\times$ disability interactions are remarkably insensitive to the list of controls and to the econometric method used to implement these controls. For men aged 21-39, for example, the 1993 year $\times$ disability interaction is -1.6 in the baseline specification, -1.9 with no controls, -1.4 with regression controls, and -1.5 with semiparametric controls.

\footnotetext{
${ }^{8}$ Standard errors for the semiparametric estimates are computed from the standard errors of the cell-specific estimates, with the weights used in averaging treated as nonrandom.
} 
Composition Bias and Other Measurement Issues

A possible explanation for the results in tables 2 and 3 is a composition effect. Figure 1 shows an increase in self-reported disability rates after 1991. If the unemployed or nonparticipants were disproportionately more likely to identify themselves as disabled after the ADA, perhaps because disability became more socially acceptable or because of the CPS redesign, the results in tables 2 and 3 could overestimate the disemployment effects of the ADA.

We investigated the possibility of composition bias using a matched sample from the 1993 and 1994 CPS. In principle, the matched sample includes two observations for half of the 1993 respondents. (In practice the match rate is lower; see the Appendix for details.) The matched sample is used to compare individuals who report a disability in both surveys to those who do not report a disability in either year. Since these surveys report data on weeks worked in 1992 and 1993, the matched data set provides a short panel that straddles the ADA's implementation date and is unaffected by changes in reporting behavior.

Results using the matched sample are reported in the Appendix, which also includes a further discussion of the consequences of the CPS redesign. Briefly, restricting the analysis to those with the same disability status in both years had little effect on the results for men aged 40-58 and women aged 21-39. This is important evidence against the presence of composition effects since disability rates between 1988 and 1996 increased more for these two groups than for the younger men. For men aged 21-39, the results using a sample in which disability status is unchanged are more mixed. But the reason may be that the March to March match rate is especially low for this group. In any case, the increase in reported disability rates for young men is not large enough to account for the results for this group. ${ }^{9}$

\section{Changes in the SSI and Disability Insurance Programs}

An important recent development affecting the labor market for disabled workers is the increase in the number of disability insurance and SSI beneficiaries (see, e.g., Bound and Burkhauser 1999). Disabled workers who worked long enough are entitled to receive disability insurance payments when not engaged in substantial gainful activity. Disabled people without a work history can receive SSI, which is a means-tested federal benefit supplemented by some states. Since SSI and disability

\footnotetext{
${ }^{9}$ Between survey years 1992 and 1995, disability rates among men aged 21-39 rose from 4.8 percent to 4.9 percent. Even if all additional workers reporting a disability worked zero weeks, this would account for only 0.4 weeks of the estimated two- to three-week decline in weeks worked between these two dates.
} 
insurance payments may have adverse labor supply effects, increased use of these programs could account for the decline in employment of the disabled. ${ }^{10}$

An investigation of the SSI/disability insurance issue is complicated by the fact that receipt of social security income is both a cause and a consequence of employment status. Estimates taking account of this endogeneity issue are reported in our working paper (Acemoglu and Angrist 1998). Since these results are similar to those reported here, we omit them. The results reported here are taken from a number of simple strategies for dealing with the growth in SSI and disability insurance rolls. In particular, since the CPS identifies social security and SSI income recipients, we can simply repeat the regressions in table 3 excluding those receiving SSI and disability insurance or use regression methods to control for beneficiary status.

Figure 3 plots the evolution of receipt of SSI and Old Age, Survivors, and Disability Insurance (OASDI) among the disabled in our sample, showing a substantial increase since 1989. The CPS does not distinguish OASDI from disability insurance, but since the sample age range is below 65 , the majority of OASDI payments are for disability insurance. Figure 3 shows that the fraction of disabled men aged 21-39 receiving disability income rose from 33 percent in 1988 to 42 percent in 1996. Bound's (1989) estimates suggest that approximately half of those receiving social security income would have otherwise worked. So the increase in SSI/ disability insurance rolls might be estimated to have reduced the employment rate among the disabled by 4.5 percentage points, close to, but still smaller than, the seven-percentage-point decline in employment rates of the disabled over the sample period (corresponding to the 3.5week decline in weeks worked for this group between 1988 and 1996). But this calculation exaggerates the importance of the increase in SSI/ disability insurance rolls. The increase in disability transfers began in 1989, whereas figure 2 shows a sharp decline in employment of the disabled following the ADA, with little change earlier, even though the disability rolls were rising. Also, while disability rolls rose more sharply for older women than for men in either age group, table 2 provides little evidence of disemployment effects for older women. These calculations therefore suggest that the rise in SSI/disability insurance rolls

\footnotetext{
${ }^{10}$ Weidenbaum (1994) attributes the decline in employment of the disabled to a growth in transfers. Although economists have long observed a strong time-series correlation between disability rolls and labor force participation (see, e.g., Parsons 1980), the labor supply consequences of disability insurance remain controversial. Bound (1989) shows that many disability applicants do not work even if they do not ultimately get disability insurance, and Bound and Burkhauser (1999) discuss the difficult identification problems that arise in research on effects of disability insurance.
} 


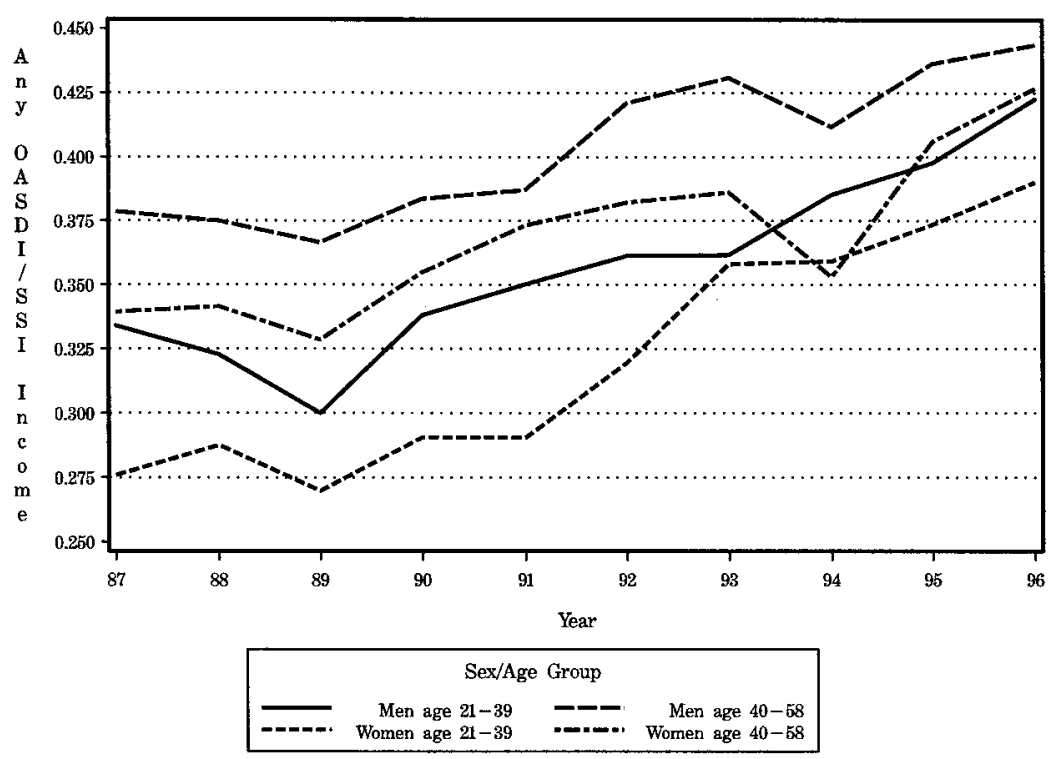

FIG. 3.-Proportion of disabled with OASDI or SSI income, men and women aged 21-58 in the 1988-97 March CPS.

is unlikely to account for the entire decline in employment of the disabled following the ADA.

Next we investigate the impact of changes in SSI and disability insurance on regression estimates. Estimates excluding social security (SSA) beneficiaries are reported in columns 1 and 2 of table 4 . For men aged 21-39, dropping beneficiaries leads to results that are typically smaller but still broadly similar to the results in table 3 . For example, the 1995 estimate changes from -3.1 to -2.7 . The 1994 estimate changes from -1.8 to -0.8 and is no longer significant, whereas the 1993 estimate increases in magnitude from -1.6 to -2.1 . For women aged 21-39, the impact of dropping transfer recipients is larger, reducing the magnitude of the estimated post-ADA effects substantially, though the effects remain large and significant. Controlling for disability-specific trends has little impact on the non-SSA estimates for men aged 21-39 but reduces the estimates for women.

Table 4 also reports the results of a regression control strategy in which a dummy for receiving OASDI or SSI is simply added to the models of table 3 (with disability $\times$ year interactions for the post-1991 years). For men aged 21-39, this reduces the magnitude of the estimated ADA effects more than simply dropping the transfer recipients. But for 
TABLE 4

Exploring the Role of SSI/Disability Insurance Benefits

\begin{tabular}{|c|c|c|c|c|}
\hline & \multicolumn{2}{|c|}{ SSA NonREcipients } & \multicolumn{2}{|c|}{ Full SAmple } \\
\hline & (1) & (2) & (3) & (4) \\
\hline & \multicolumn{4}{|c|}{ A. Men Aged 21-39 } \\
\hline Disability main effect & $-17.7(.30)$ & $-17.6(.72)$ & $-18.1(.26)$ & $20.5(.69)$ \\
\hline Disability $\times 1991$ & $-1.47(.65)$ & $-1.35(.93)$ & $-.33(.54)$ & $-.22(.55)$ \\
\hline Disability $\times 1992$ & $-.05(.65)$ & $.11(1.13)$ & $.99(.53)$ & $.70(.54)$ \\
\hline Disability $\times 1993$ & $-2.08(.64)$ & $-1.86(1.35)$ & $-.98(.53)$ & $-.78(.54)$ \\
\hline Disability $\times 1994$ & $-.79(.67)$ & $-.53(1.60)$ & $-.78(.54)$ & $-1.15(.55)$ \\
\hline Disability $\times 1995$ & $-2.67(.71)$ & $-2.36(1.86)$ & $-1.81(.57)$ & $-2.49(.58)$ \\
\hline Disability $\times 1996$ & $-1.79(.70)$ & $-1.43(2.11)$ & $-1.14(.55)$ & $-1.94(.57)$ \\
\hline Disability $\times$ linear trend & & $-.05(.26)$ & & \\
\hline Receives OASDI/SSI & & & $-18.2(.26)$ & \\
\hline $\begin{array}{l}\text { OASDI/SSI incidence and } \\
\text { disability/year }\end{array}$ & & & & \\
\hline interactions & no & no & no & yes \\
\hline \multirow[t]{2}{*}{ Observations } & 189,136 & 189,136 & 193,317 & 193,317 \\
\hline & \multicolumn{4}{|c|}{ B. Women Aged 21-39 } \\
\hline Disability main effect & $-11.0(.44)$ & $-10.6(1.07)$ & $-11.0(.38)$ & $11.6(1.36)$ \\
\hline Disability $\times 1991$ & $1.06(.95)$ & $1.45(1.36)$ & $.67(.81)$ & $.25(.82)$ \\
\hline Disability $\times 1992$ & $-1.52(.93)$ & $-.98(1.64)$ & $-1.91(.78)$ & $-1.87(.79)$ \\
\hline Disability $\times 1993$ & $-2.97(.95)$ & $-2.28(1.98)$ & $-3.18(.78)$ & $-2.92(.82)$ \\
\hline Disability $\times 1994$ & $-3.81(.94)$ & $-2.97(2.33)$ & $-3.76(.77)$ & $-3.39(.82)$ \\
\hline Disability $\times 1995$ & $-2.01(.94)$ & $-1.02(2.69)$ & $-2.53(.77)$ & $-2.55(.81)$ \\
\hline Disability $\times 1996$ & $-2.22(.98)$ & $-1.08(3.07)$ & $-2.82(.79)$ & $-2.82(.85)$ \\
\hline Disability $\times$ linear trend & & $-.15(.39)$ & & \\
\hline Receives OASDI/SSI & & & $-11.5(.28)$ & \\
\hline $\begin{array}{l}\text { OASDI/SSI incidence and } \\
\text { disability/year }\end{array}$ & & & & \\
\hline interactions & no & no & no & yes \\
\hline \multirow[t]{2}{*}{ Observations } & 205,355 & 205,355 & 211,901 & 211,910 \\
\hline & \multicolumn{4}{|c|}{ C. Men Aged 40-58 } \\
\hline Disability main effect & $-22.6(.24)$ & $-21.9(.59)$ & $-22.0(.21)$ & $28.7(.76)$ \\
\hline Disability $\times 1991$ & $.90(.52)$ & $1.56(.74)$ & $.90(.42)$ & $.29(.44)$ \\
\hline Disability $\times 1992$ & $2.31(.51)$ & $3.25(.90)$ & $1.93(.41)$ & $.77(.43)$ \\
\hline Disability $\times 1993$ & $-1.26(.51)$ & $-.05(1.08)$ & $-.64(.41)$ & $-1.99(.43)$ \\
\hline Disability $\times 1994$ & $-.95(.49)$ & $.53(1.27)$ & $-.54(.40)$ & $-1.56(.42)$ \\
\hline Disability $\times 1995$ & $-.71(.50)$ & $1.03(1.47)$ & $-.25(.39)$ & $-1.79(.41)$ \\
\hline Disability $\times 1996$ & $1.14(.50)$ & $3.15(1.67)$ & $-1.00(.39)$ & $-.84(.41)$ \\
\hline Disability $\times$ linear trend & & $-.27(.21)$ & & \\
\hline Receives OASDI/SSI & & & $-21.7(.19)$ & \\
\hline $\begin{array}{l}\text { OASDI/SSI incidence } \\
\text { and disability/year }\end{array}$ & & & & \\
\hline interactions & no & no & no & yes \\
\hline Observations & 139,372 & 139,372 & 146,309 & 146,309 \\
\hline
\end{tabular}


women, the regression control strategy has less of an effect than dropping the transfer recipients.

As a final check on the SSI/disability insurance hypothesis, we included the proportion of disabled workers in each state and year receiving SSI or OASDI payments, allowing separate effects of state transfer incidence by year and disability status. These results are reported in column 4 and are similar to the earlier results. Overall, this investigation suggests that SSI and disability insurance trends do not account for most of the post-ADA decline in the relative employment of disabled men and women aged 21-39. The results for men aged 40-58 are weaker in the sample that excludes social security beneficiaries. On the other hand, the estimates allowing for endogenous receipt of disability in Acemoglu and Angrist (1998) again show sizable employment declines for this subsample.

\section{Magnitudes}

The estimates in tables 2 and 3 can be compared to estimates of the effect of the ADA on the costs of employing disabled workers to see whether the response has a plausible magnitude. Unfortunately, there are no good estimates of ADA costs, so our calculations are really just educated guesses. Between 1993 and 1997, the average ADA charge rate was about 12 per 1,000 disabled employees a year. In 14 percent of the ADA charges filed with the EEOC that were also resolved by the EEOC, employers made average payments of over $\$ 15,000$ per case. In the remaining cases, the charge was dropped or is pending or there was a suit. We do not know what fraction of ADA charges end up in court. However, between 1995 and 1997, roughly 56,000 employment discrimination cases were brought in federal court (Administrative Offices of U.S. Courts 1997). The total number of employment discrimination charges filed directly with the EEOC during this period was 245,000, which implies that 23 percent of these charges may have gone to court. We apply this fraction to all ADA charges and use two estimates for the cost of a lawsuit. The first is a figure of $\$ 210,000$ per case quoted by Condon and Zolna (1997), and the second is the $\$ 15,000$ that applies for cases resolved by the EEOC. We also assume that if an ADA charge does not go to court or get settled by the EEOC, there are no other costs. The higher estimate of the average cost of an ADA charge filed with the EEOC is therefore equal to $0.23 \times 210,000+0.14 \times$ $15,000=\$ 50,400$, and the lower estimate is $0.37 \times 15,000=\$ 5,550$. If one assumes that this amount applies to ADA charges handled by state FEP agencies as well, the higher estimate is $50,400 \times 0.012=\$ 605$ a year per disabled employee for the cost of the ADA. This translates into 
a $\$ 12$ cost for each week of exposure to the risk of a suit. With similar calculations, the lower estimate is $\$ 1.50$ per week.

Assessing the cost of reasonable accommodation is even harder. The Job Accommodation Network (1997) reports a monetary cost of $\$ 930$ per accommodation, which we take as the net cost, though this might be an underestimate. ${ }^{11}$ Estimated separation rates suggest that the average duration of a job held by a disabled employee is 10 months. This implies that accommodation leads to a $\$ 23$ increase in weekly employment costs. When this is combined with the estimated costs of lawsuits, the total weekly cost increase due to the ADA ranges from $1.5+$ $23=\$ 24.5$ to $12+23=\$ 35$. Since the average weekly earnings of the disabled were about \$365 in 1991 and 1992, this implies that the ADA led to an increase in the cost of employing disabled workers of 6-10 percent.

In the theoretical model in Section III, employers take the total cost of labor as given and are always on their labor demand curve. Since the results in table 2 show little evidence of a change in wages of the disabled, the cost increase generated by the ADA falls on employers. The 10-15 percent decline in weeks worked is therefore consistent with demand elasticities of about -1 to -2 for disabled workers. This is in the range of elasticity estimates reported by Hamermesh (1986) for workers in different demographic groups, and in any case, a high elasticity of substitution between disabled and nondisabled workers seems likely. ${ }^{12}$

Finally, we should note that the negative effects of the ADA seem to peak in 1994 or 1995. If accommodation costs are important, as suggested by the calculations here, and if some of the accommodation costs are fixed, the negative impact on employment of the disabled generated by these costs may shrink. Also, employer concern about firing costs may be fueled partly by high-profile cases. Once the relevant common law is well developed, negative effects due to uncertain liability risks may recede.

\section{B. The Impact of the ADA on Hiring and Separations}

We used matched CPS rotation groups from March to April to investigate the effect of the ADA on hiring and separation rates (see the Appendix for a detailed description of the match). An individual is coded as having experienced a separation in year $t$ if he or she is employed in March of that year and not in April. Similarly, an accession (hire) is recorded

\footnotetext{
${ }^{11}$ This number excludes any increases in productivity due to accommodation, any losses from task changes or suboptimal reorganization of the work environment, and the time costs of dealing with the ADA.

${ }^{12}$ It is worth noting that turnover rates among disabled workers are high, so a small decline in the hiring rate for the disabled leads to sharp drops in employment.
} 
when someone who was not employed in March is employed in April. Separations are defined for those working in March and accessions are defined for those not working in March. Disability status always refers to March. These measures of accessions and separations are the same as those used by Poterba and Summers (1986), and the resulting average accession and separation rates are close to the rates they report.

The estimates of effects on separations and accessions are imprecise and also are potentially affected by the CPS redesign (since the underlying data come from the main CPS survey and not the supplement). Moreover, Poterba and Summers (1986) show that labor market transition data are plagued by considerable measurement error. We therefore limit the discussion in this subsection to a brief graphical analysis.

Figure 4 plots log separation rates by disability status, sex, and age group. ${ }^{13}$ Figure $4 a$ shows a post-ADA decline in separation rates for disabled workers aged 21-39, but there is also a smaller decline for the nondisabled. The results in figure $4 b$ for the older age group show even less evidence of a clear post-ADA decline in the separation rates of disabled workers. The lack of a clear reduction in separation rates of the disabled weighs against a pure "firing costs" model of the ADA, though this result might also reflect substantial measurement error in the estimated separation rates.

Figure 5 plots the corresponding log accession rates. Figure $5 a$ shows a sizable decline in the hiring rates of disabled workers aged 21-39 and no decline for the nondisabled. Figure $5 b$ shows some evidence of a relative decline in hiring for disabled men in the older group. The apparent reductions in hiring for men and younger women are not surprising since employment for these groups fell.

\section{Results by Firm Size}

As a further check on the hypothesis that the decline in employment of the disabled after 1992 was caused by the ADA, we looked at employment patterns by firm size. This is of interest because firms with fewer than 15 employees are not covered by the ADA and those with 16-25 employees were initially exempt. The ADA might also have had a larger effect on employment in small firms since, as noted in Section III, small firms are probably less able to absorb ADA-related costs. Together, these considerations suggest that we might expect the ADA to have had the largest effect on employment in firms that are sufficiently

\footnotetext{
${ }^{13}$ Let $e, \eta$, and $\zeta$ be the employment, accession, and separation rates. Then $e \approx$ $\eta /(\eta+\zeta)$ in the steady state. Log accession and separation rates are plotted because

$$
\frac{d e}{d x} \approx\left(\frac{d \log \eta}{d x}-\frac{d \log \zeta}{d x}\right) \cdot[e \cdot(1-e)]
$$
}



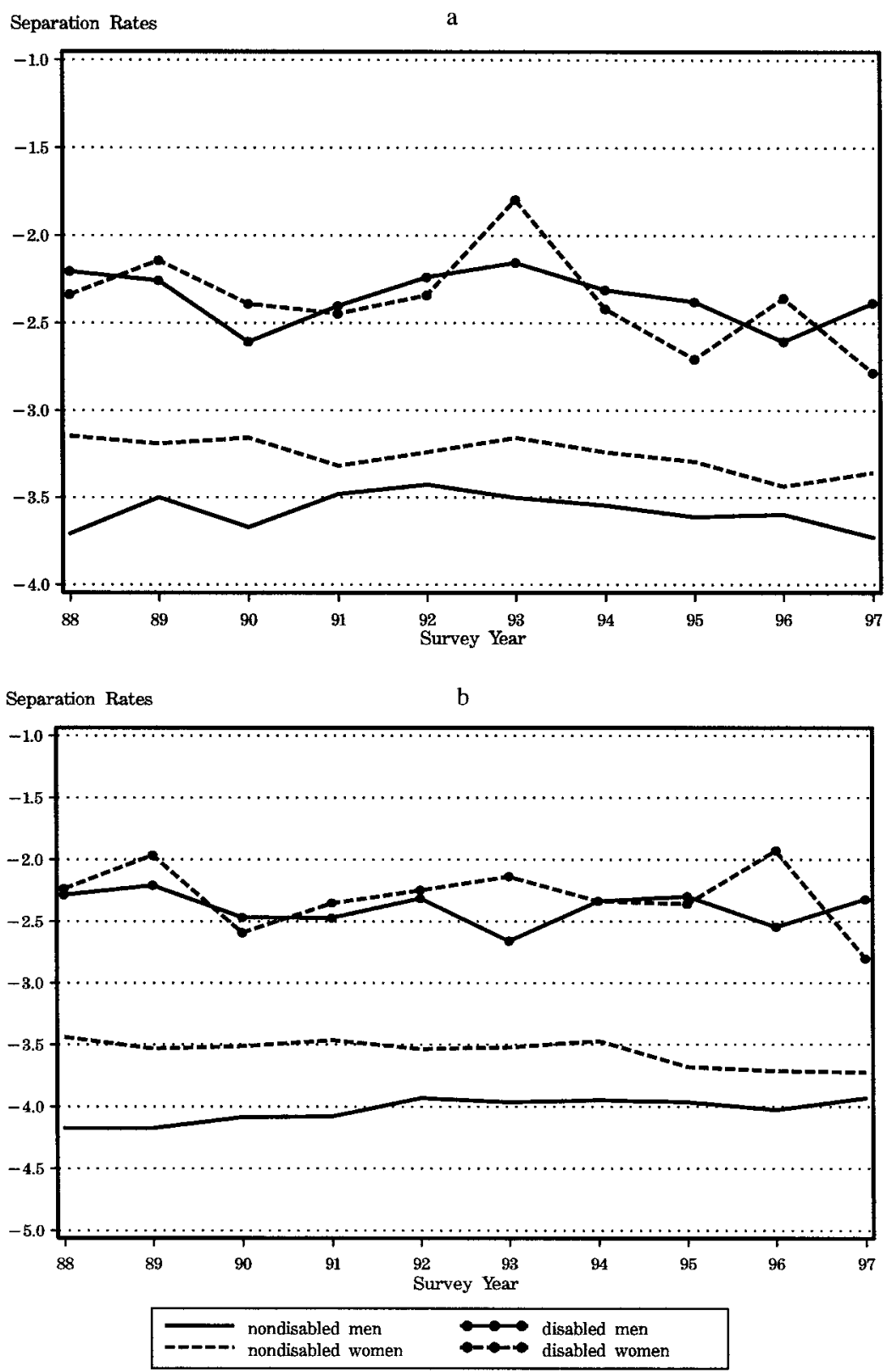

Fig. 4.- $(\log )$ separation rates by disability status and sex. $a$, CPS respondents aged 21-39. $b$, CPS respondents aged 40-58. 

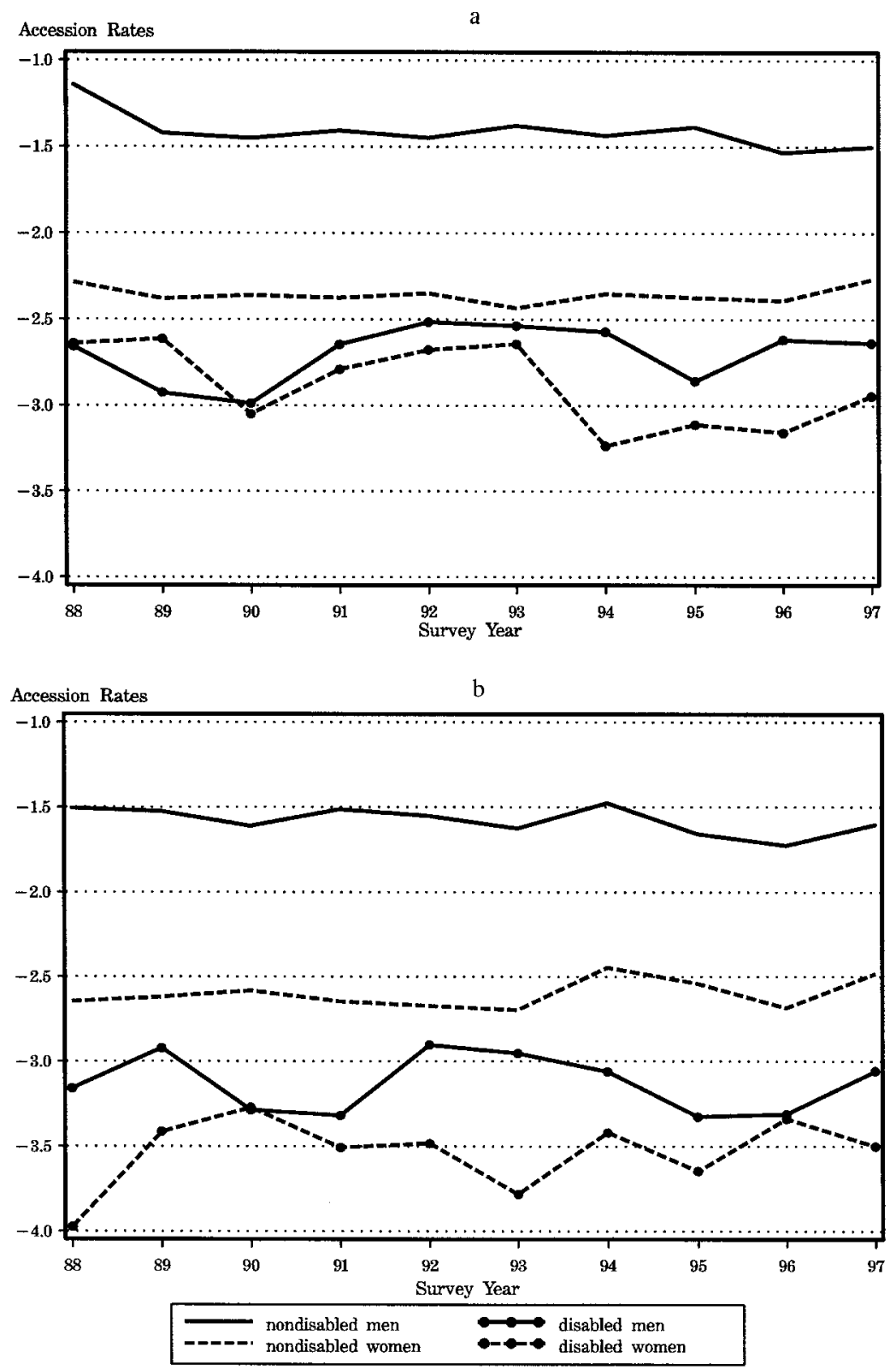

FIG. 5.- $(\log )$ accession rates by disability status and sex. $a$, CPS respondents aged 21-39. $b$, CPS respondents aged 40-58. 
large to be covered by ADA provisions but small enough to be vulnerable to an increase in costs.

Respondents to the CPS supplement provide information on the size of the employer they worked for longest in the past year. Responses to this question are grouped into three brackets: 1-24 employees (small), 25-99 employees (medium), and 100 or more employees (large). Figure 6 plots the $\log$ of the probability of working in these three firm size categories divided by the probability of not working. The figures give a visual representation of the coefficients in a multinomial logit model in which the dependent variable is employment by size category, and nonworkers are the reference group. The independent variables are year effects. The log odds in each figure were computed separately for disabled and nondisabled workers.

The log odds of working in a medium-size firm appear to have fallen somewhat more steeply than the log odds of working in a small firm after 1992 for disabled men of all ages and women aged 21-39. For women aged 21-39, there is also a relative decline in the probability of working in a large firm. Estimates of these differing trends by firm size are not very precise (e.g., $t=1.4$ for the medium vs. small contrast for men aged 21-39), but they are negative for all three of our main demographic groups. In contrast with this pattern, the log odds of employment by firm size are essentially parallel for nondisabled workers, suggesting that the $\mathrm{ADA}$ had no effect on the nondisabled. Of course, even if there were effects on the nondisabled, it seems likely that they would be much smaller than effects on the disabled and therefore harder to detect.

\section{Cross-State Variation in ADA Charge Rates}

Our final strategy connects changes in employment with state-level variation in ADA charge rates calculated from EEOC data. Like the firmsize analysis, this strategy allows us to separately identify the impact of the ADA on employment of the disabled and the nondisabled. For the purposes of this analysis, the ADA charge rate is defined as the number of ADA-related discrimination charges in a given state and year divided by the disabled population $(\times 1,000)$ in that state and year calculated from the CPS. This measure is lagged once, so weeks worked in, say, 1996 are matched with charge rates in 1995.

Charge rates vary considerably by state. For example, the average charge rate for 1993 is 3.6 per 1,000 disabled persons aged 21-58, varying from a minimum of $1 / 1,000$ to a maximum of $10 / 1,000$. Variation in charge rates is generated by idiosyncratic differences in state labor force composition, local awareness of ADA provisions, cross-state differences in employers' compliance with the ADA, and whether a state 

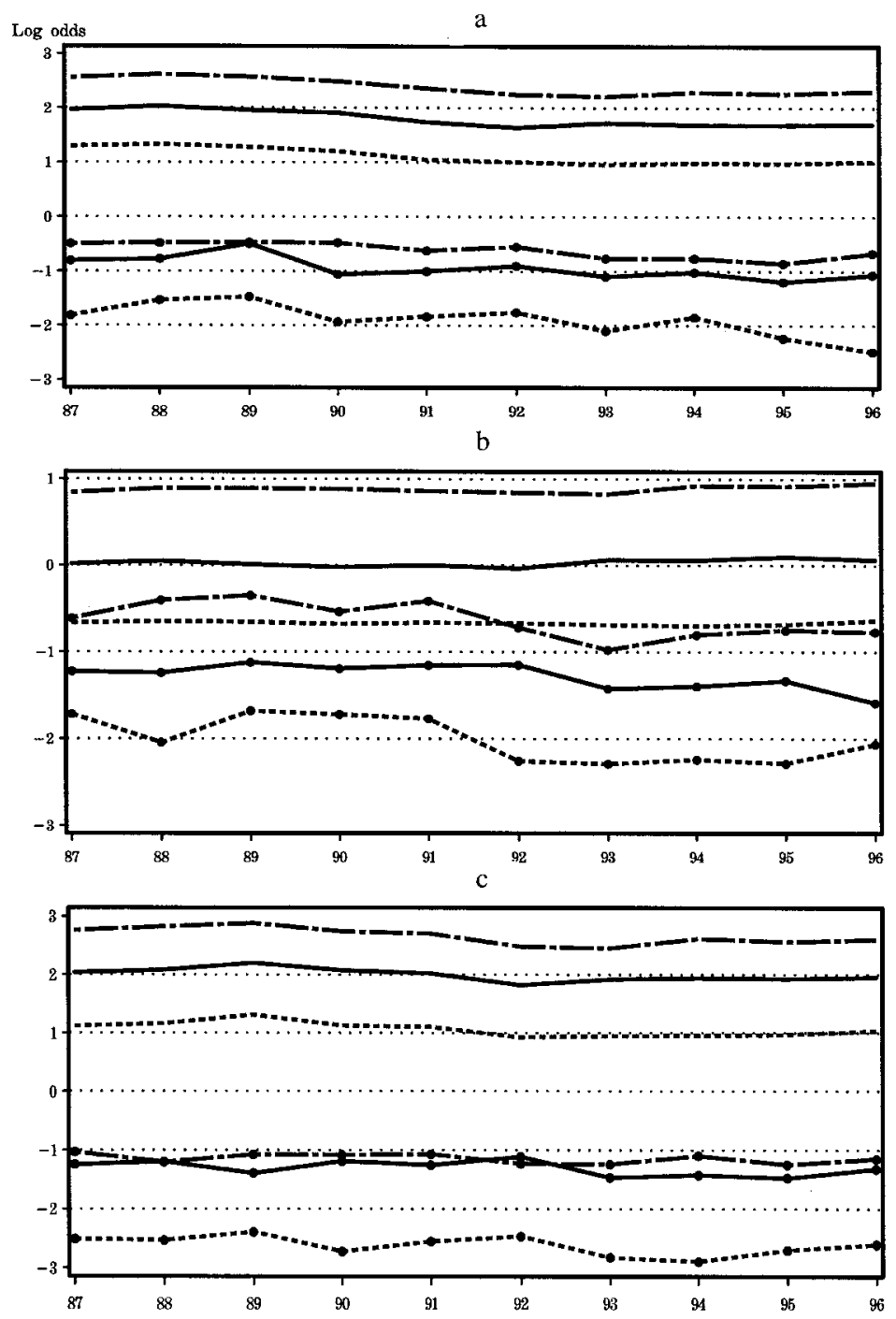

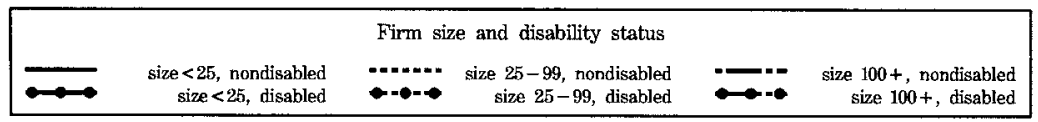

FIG. 6.-Multinomial logit plot of log employment probabilities by firm size and disability status. The reference group consists of nonworkers. $a$, Men aged 21-39. $b$, Women aged 21-39. $c$, Men aged 40-58. 
previously had an FEP statute that covered disabled workers. Some states had weak laws; others had laws that set criminal as well as civil penalties in cases in which discrimination is proved (Percy 1989). For states with weaker protection for the disabled, the ADA was a more important innovation.

The first results using state variation were computed by OLS estimation of the following equation estimated separately for each disability group, $d$ :

$$
y_{i t}=x_{i}^{\prime} \cdot \pi_{d}+\phi_{d s}+\varphi_{d t}+\gamma_{d t} \cdot r_{s, t-1}+\epsilon_{i b},
$$

where $\gamma_{d t}$ is normalized to zero for $t<93, \phi_{d s}$ is a state effect, and $\varphi_{d t}$ is a year effect. The parameters of interest are now $\gamma_{d, 99}, \gamma_{d, 94}, \gamma_{d, 95}$, and $\gamma_{d, 96}$, that is, interactions between year effects and charge rates (per disabled person) in the previous year in the individual's state of residence (e.g., $\left.r_{s, 92}\right)$. We also report estimates from a model that includes linear time trends for each state. Because (9) is estimated separately for each disability group, the identification strategy here no longer uses the nondisabled as a control group for the disabled. Rather, evidence of ADA effects comes from a finding that employment of the disabled fell more in states with more ADA-related EEOC charges.

The results in table 5 show that after the ADA, weeks worked by disabled men living in states with a large number of ADA charges declined relative to other states. For men aged $21-39$, a 25 percent increase in the mean annual charge rate of about $4 / 1,000$ is predicted to reduce employment by 2.3 weeks on the basis of the 1993 estimate and by 1.3 weeks on the basis of the 1994 estimate. These results are robust to the inclusion of state-specific trends, though they disappear later in the sample. The results for women aged 21-39 show no significant decline in employment of the disabled in the years immediately following the ADA, but there are significant negative effects for this group in 1996. For older men, the effects are also negative, but often statistically insignificant, except for a very large effect in 1993.

In contrast with the estimates for the disabled, there is no consistent evidence of a negative impact of ADA charges on the nondisabled. The only significant negative estimates for the nondisabled appear in models that control for linear trends. For the most part, these estimates are also considerably smaller than the corresponding estimates for the disabled.

To further investigate the role of SSI/disability insurance in accounting for the decline in employment of the disabled, we also added to equation (9) the proportion of the disabled population in the relevant demographic group receiving social security benefits in that state and year. These estimates are reported in columns 3, 6, and 9. The results from models controlling for the proportion of beneficiaries of SSI/ 
TABLE 5

Post-ADA Interactions with EEOC Charge Rates: OLS Estimates

\begin{tabular}{|c|c|c|c|c|c|c|c|c|c|}
\hline \multirow[b]{2}{*}{ YEAR } & \multicolumn{3}{|c|}{ MEn Aged 21-39 } & \multicolumn{3}{|c|}{ WoMEn AgEd 21-39 } & \multicolumn{3}{|c|}{ MEN Aged 40-58 } \\
\hline & $\begin{array}{l}\text { No Trend } \\
\text { (1) }\end{array}$ & $\begin{array}{l}\text { Trend } \\
(2)\end{array}$ & $\begin{array}{c}\text { SSI or DI } \\
(3)\end{array}$ & $\begin{array}{l}\text { No Trend } \\
\text { (4) }\end{array}$ & $\begin{array}{l}\text { Trend } \\
(5)\end{array}$ & $\begin{array}{l}\text { SSI or DI } \\
(6)\end{array}$ & $\begin{array}{l}\text { No Trend } \\
(7)\end{array}$ & $\begin{array}{l}\text { Trend } \\
(8)\end{array}$ & $\begin{array}{c}\text { SSI or DI } \\
(9)\end{array}$ \\
\hline & \multicolumn{9}{|c|}{ A. Disabled } \\
\hline $\begin{array}{l}1993 \\
1994 \\
1995 \\
1996 \\
\text { SSI or DI }\end{array}$ & $\begin{aligned}-2.29 & (1.81) \\
-1.32 & (.54) \\
-.61 & (.56) \\
.49 & (.57)\end{aligned}$ & $\begin{array}{r}-2.62(1.97) \\
-1.36(.64) \\
-.42(.70) \\
.58(.78)\end{array}$ & $\begin{aligned} &-2.28(1.81) \\
&-1.11(.54) \\
&-.61(.56) \\
& .71(.57) \\
&-16.0(4.65)\end{aligned}$ & $\begin{aligned} & 1.73(1.73) \\
&-.70(.49) \\
&-.14(.47) \\
&-1.60(.53)\end{aligned}$ & $\begin{aligned} 1.27(1.87) \\
-.96(.58) \\
-.57(.61) \\
-2.26(.72)\end{aligned}$ & $\begin{aligned} 1.65(1.73) \\
-.42(.50) \\
-.13(.47) \\
-1.36(.53) \\
-22.1(4.52)\end{aligned}$ & $\begin{aligned}-4.92(1.50) \\
-.32(.41) \\
-.03(.38) \\
-.12(.41)\end{aligned}$ & $\begin{aligned}-4.91(1.60) \\
-.36(.48) \\
-.04(.50) \\
-.16(.58)\end{aligned}$ & $\begin{aligned} &-5.05(1.50) \\
&-.12(.41) \\
&-.01(.38) \\
& .05(.41) \\
&-15.5(3.67)\end{aligned}$ \\
\hline SSI or DI & \multicolumn{9}{|c|}{ B. Nondisabled } \\
\hline $\begin{array}{l}1993 \\
1994 \\
1995 \\
1996 \\
\text { SSI or DI }\end{array}$ & $\begin{array}{l}.61(.28) \\
.08(.08) \\
.10(.07) \\
.06(.08)\end{array}$ & $\begin{array}{l}-.03(.30) \\
-.21(.09) \\
-.22(.09) \\
-.32(.11)\end{array}$ & $\begin{array}{r}.61(.28) \\
.04(.08) \\
.10(.07) \\
.03(.08) \\
2.28(.68)\end{array}$ & $\begin{array}{l}.09(.39) \\
.13(.11) \\
.26(.11) \\
.11(.11)\end{array}$ & $\begin{aligned} &-.21(.42) \\
& .02(.13) \\
& .15(.14) \\
& .01(.15)\end{aligned}$ & $\begin{array}{r}.09(.39) \\
.13(.11) \\
.26(.11) \\
.12(.11) \\
-.16(.96)\end{array}$ & $\begin{array}{r}.70(.29) \\
.25(.08) \\
.30(.07) \\
-.04(.07)\end{array}$ & $\begin{array}{r}.33(.31) \\
.07(.09) \\
.05(.10) \\
-.30(.11)\end{array}$ & $\begin{array}{r}.70(.29) \\
.22(.08) \\
.30(.07) \\
-.05(.07) \\
1.82(.70)\end{array}$ \\
\hline
\end{tabular}


disability insurance by state and year are similar to those reported elsewhere in the table.

In a final strategy, we experimented with two-stage least-squares (2SLS) estimation of equation (9), treating the charge rate as endogenous. If differences in charge activity across states vary primarily because of local economic conditions or lower compliance by employers, negative estimates of $\gamma_{d, 93}, \gamma_{d, 94}, \gamma_{d, 95}$, and $\gamma_{d, 96}$ need not indicate a causal link between charge rates and employment of the disabled. This motivates us to instrument for state charge rates using interactions between post-ADA year dummies and a dummy for whether a state previously had a strong FEP law penalizing discrimination against the disabled. ${ }^{14}$ A dummy for preexisting state FEP laws is negatively correlated with ADA charge rates in every year from 1992 on. In 1995, for example, charge rates were about 20 percent lower in states with a preexisting FEP statute with sanctions.

The instrumental variables estimates using FEP dummies as instruments, along with the corresponding OLS regressions, are reported in table 6 . Since the charge rate is now instrumented, it is no longer lagged. The instrumental variables estimates show a pattern similar in some respects to that observed in table 5, though they are larger and, not surprisingly, considerably less precise. For example, the 1993 estimate for disabled men is now -4.9 as compared to -2.3 in table 5 and is only marginally significant. Estimates for young men in later years are positive. The 2SLS estimates for young women, like the OLS estimates in table 5, are most negative in 1996 and in fact more consistently negative than the corresponding OLS estimates in table 6. For men aged 40-58, the instrumental variables estimates are also more negative than the corresponding OLS estimates. Overall, these findings provide some evidence that states in which the ADA was more of an innovation experienced steeper declines in employment of the disabled than other states.

\section{Concluding Comments}

Some social critics see the ADA as part of a process eroding the traditional employment-at-will doctrine and making the U.S. labor market more like that of Europe. In contrast, ADA proponents see the ADA as making the labor market more inclusive, without appreciably increasing employer costs or reducing employment. Economic theory suggests avenues for inquiry but does not make unambiguous predictions.

In 1993, the year after the ADA came into effect, there were marked

\footnotetext{
${ }^{14}$ That is, an FEP law with sanctions. Many states had FEP laws without any sanctions. Information on charge rates is obtained from Percy (1989). See the Appendix for details.
} 
TABLE 6

Instrumental Variables Estimates of Charge Rate Effects

\begin{tabular}{|c|c|c|c|c|c|c|}
\hline \multirow[b]{2}{*}{ YEAR } & \multicolumn{2}{|c|}{ Men AgEd 21-39 } & \multicolumn{2}{|c|}{$\begin{array}{c}\text { WOMEN AGED } \\
21-39\end{array}$} & \multicolumn{2}{|c|}{ Men Aged 40-58 } \\
\hline & $\begin{array}{l}\text { OLS } \\
(1)\end{array}$ & $\begin{array}{l}\text { 2SLS } \\
(2)\end{array}$ & $\begin{array}{l}\text { OLS } \\
(3)\end{array}$ & $\begin{array}{l}\text { 2SLS } \\
(4)\end{array}$ & $\begin{array}{l}\text { OLS } \\
(5)\end{array}$ & $\begin{array}{l}\text { 2SLS } \\
(6)\end{array}$ \\
\hline & \multicolumn{6}{|c|}{ A. Disabled } \\
\hline 1992 & $\begin{array}{c}-2.79 \\
(1.84)\end{array}$ & $\begin{array}{l}-7.75 \\
(9.37)\end{array}$ & $\begin{array}{l}1.23 \\
(1.83)\end{array}$ & $\begin{array}{c}-.51 \\
(10.1)\end{array}$ & $\begin{array}{c}-1.12 \\
(1.51)\end{array}$ & $\begin{array}{l}-7.84 \\
(10.1)\end{array}$ \\
\hline 1993 & $\begin{array}{r}-1.13 \\
(.51)\end{array}$ & $\begin{array}{c}-4.98 \\
(2.89)\end{array}$ & $\begin{array}{l}1.41 \\
(.49)\end{array}$ & $\begin{array}{c}.04 \\
(3.99)\end{array}$ & $\begin{array}{l}-.76 \\
(.42)\end{array}$ & $\begin{array}{r}-2.70 \\
(3.52)\end{array}$ \\
\hline 1994 & $\begin{array}{r}-1.27 \\
(.50)\end{array}$ & $\begin{array}{c}1.67 \\
(2.43)\end{array}$ & $\begin{array}{l}.04 \\
(.47)\end{array}$ & $\begin{array}{c}3.02 \\
(2.27)\end{array}$ & $\begin{array}{l}-.05 \\
(.39)\end{array}$ & $\begin{array}{l}-.51 \\
(2.50)\end{array}$ \\
\hline 1995 & $\begin{array}{l}-.72 \\
(.59)\end{array}$ & $\begin{array}{l}3.58 \\
(2.74)\end{array}$ & $\begin{array}{l}.32 \\
(.51)\end{array}$ & $\begin{array}{c}-1.75 \\
(2.15)\end{array}$ & $\begin{array}{r}-.08 \\
(.42)\end{array}$ & $\begin{array}{r}-2.07 \\
(2.37)\end{array}$ \\
\hline 1996 & $\begin{array}{l}-.24 \\
(.52)\end{array}$ & $\begin{array}{c}2.65 \\
(2.99)\end{array}$ & $\begin{array}{l}-.48 \\
(.47)\end{array}$ & $\begin{array}{c}-5.46 \\
(2.53)\end{array}$ & $\begin{array}{r}-.05 \\
(.36)\end{array}$ & $\begin{array}{r}-3.10 \\
(2.77)\end{array}$ \\
\hline \multirow[t]{2}{*}{ Observations } & \multicolumn{2}{|c|}{9,109} & \multicolumn{2}{|c|}{8,842} & \multicolumn{2}{|c|}{14,093} \\
\hline & \multicolumn{6}{|c|}{ B. Nondisabled } \\
\hline 1992 & $\begin{array}{l}.44 \\
(.28)\end{array}$ & $\begin{array}{c}3.54 \\
(1.21)\end{array}$ & $\begin{array}{l}.26 \\
(.39)\end{array}$ & $\begin{array}{c}2.05 \\
(1.80)\end{array}$ & $\begin{array}{l}.32 \\
(.29)\end{array}$ & $\begin{array}{c}3.44 \\
(1.36)\end{array}$ \\
\hline 1993 & $\begin{array}{l}.24 \\
(.08)\end{array}$ & $\begin{array}{l}.85 \\
(.40)\end{array}$ & $\begin{array}{l}.07 \\
(.11)\end{array}$ & $\begin{array}{l}-.09 \\
(.60)\end{array}$ & $\begin{array}{l}.27 \\
(.08)\end{array}$ & $\begin{array}{l}1.57 \\
(.45)\end{array}$ \\
\hline 1994 & $\begin{array}{l}.11 \\
(.07)\end{array}$ & $\begin{array}{c}-.42 \\
(.30)\end{array}$ & $\begin{array}{l}.06 \\
(.11)\end{array}$ & $\begin{array}{l}.89 \\
(.46)\end{array}$ & $\begin{array}{l}.27 \\
(.08)\end{array}$ & $\begin{array}{l}.83 \\
(.34)\end{array}$ \\
\hline 1995 & $\begin{array}{l}.08 \\
(.08)\end{array}$ & $\begin{array}{l}.68 \\
(.28)\end{array}$ & $\begin{array}{l}.17 \\
(.11)\end{array}$ & $\begin{array}{l}1.24 \\
(.43)\end{array}$ & $\begin{array}{l}.31 \\
(.08)\end{array}$ & $\begin{array}{l}.99 \\
(.29)\end{array}$ \\
\hline 1996 & $\begin{array}{l}-.01 \\
(.07)\end{array}$ & $\begin{array}{l}.89 \\
(.35)\end{array}$ & $\begin{array}{l}.13 \\
(.10)\end{array}$ & $\begin{array}{l}.99 \\
(.51)\end{array}$ & $\begin{array}{l}.01 \\
(.07)\end{array}$ & $\begin{array}{l}.66 \\
(.33)\end{array}$ \\
\hline Observations & \multicolumn{2}{|c|}{184,208} & \multicolumn{2}{|c|}{203,068} & \multicolumn{2}{|c|}{132,216} \\
\hline
\end{tabular}

NoTE. - Standard errors are reported in parentheses. The table reports OLS and 2SLS estimates from regressions of weeks worked on the state-level ADA charge rate. These models include age, race, education, state, and year main effects. Regressions are estimated separately by disability status. The instruments consist of dummies for 16 states with strong pre-ADA anti-disability discrimination statutes, interacted with year effects.

drops in the employment of disabled men aged 21-39, both in absolute terms and relative to the nondisabled. A similar drop is observed in 1992 for disabled women aged 21-39. Extrapolating employment trends, allowing for composition effects, and controlling for changes in disability insurance and SSI participation rates do not seem to account for these declines, leaving the ADA as a likely cause. This interpretation is also supported by evidence that employment of disabled men fell more sharply in states with more ADA-related charge activity and by relative declines in the employment of disabled workers in medium-size firms.

In contrast to the results for younger groups, we find no decline in the employment of disabled women aged 40-58. Moreover, in some specifications the decline in the employment of disabled men aged 40-58 can be accounted for by increased transfers. A possible explanation for the difference in findings by age and sex is that before the 
advent of the ADA, workers over 40 were already protected by the Age Discrimination in Employment Act (ADEA), and women over 40 were protected by both the ADEA and Title VII. Charge statistics for the ADA based on sex show that charge rates per disabled worker were in fact lowest for women aged 40-58 in every year after $1993 .{ }^{15}$

Since the ADA provides a form of employment protection, it should lead to a lower separation rate for the disabled. Because we found no evidence of an effect of the ADA on separations of the disabled, the employment protection story does not get direct empirical support, though this may reflect measurement error in the estimated separation rates. This result and the fact that the costs of reasonable accommodation are probably larger than the costs of litigation for wrongful termination suggest that accommodation costs have been at least as important for employers as the fear of lawsuits. The absence of an offsetting decline in wages suggests that the equal-pay provision has also played a role in the ADA's employment effects. Finally, using empirical strategies that look separately at disabled and nondisabled workers, we found no evidence of negative effects on the nondisabled. Contrary to the concerns of its fiercest opponents (e.g., Olson 1997), it seems highly unlikely that the ADA led to a climate of fear of litigation that significantly reduced the overall level of employment.

\section{Appendix}

\section{A. Basic Data Issues}

All our estimates are weighted by CPS sample weights, updated to reflect population counts from the 1990 Census. The 1988 CPS data come from the socalled March "rewrite" file. This file includes firm size and other variables not on the original 1988 release and reflects a revised imputation procedure (Bureau of the Census 1991). The extract excludes the Hispanic oversample for each year. A few dozen households with duplicate household identifiers in the 1994 survey were also excluded because they could not be included in the matched samples.

\section{B. March 1993 to March 1994 Match}

In principle, households in rotation groups 1-4 in 1993 are interviewed in March 1994 when they are in rotation groups 5-8. In practice, some of these households move or are lost for other reasons. For the purposes of the 1993/94 match, we selected individuals in the relevant rotation groups with valid interview status (CPS item H-HHTYPE $=1$ ) and in the age range of interest (21-58 for 1993 and 21-60 for 1994). Records were matched using the household identifier (CPS item H-IDNUM), person line number (CPS item A-LINENO), and rotation

\footnotetext{
${ }^{15}$ For example, in 1995, women aged 40-58 filed 78 charges per 1,000 disabled workers, whereas men aged 40-58 filed 93/1,000 charges, women aged 21-39 filed 91/1,000 charges, and men aged 21-39 filed 87/1,000 charges.
} 
group (i.e., 1994 H-MIS equaled 1993 H-MIS plus four). Of the March 1993 records eligible for matching, 76 percent were matched to a March 1994 record.

We defined a successful match as a person with the same sex and race in both years. According to this definition, 70.9 percent of eligible March 1993 records were matched, a rate similar to that reported in Peracchi and Welch (1995); 93 percent of the records that satisfied the basic match restrictions were also matched on sex and race. Because the household identifier on the 1994 file from the Interuniversity Consortium for Political and Social Sciences is incorrect, the matched data use a corrected household identifier for 1994 provided by the Census Bureau.

\section{Analysis of Matched Data}

The matched data can be used to look at both composition effects and the impact of the CPS redesign. As noted in the text, the redesign changed the main questionnaire and instituted universal computer-assisted interviewing (see, e.g., Polivka 1996). The supplement questionnaire was unchanged, but these other changes may have affected the nature or likelihood of supplement responses. A parallel survey conducted in 1993 showed few differences between results from computer-assisted and paper and pencil interviews for the supplement. Later, however, it was discovered that some of the annual income and earnings data collected in the 1994 supplement were mistakenly collected for subannual amounts (Bureau of the Census 1994). The problem appears to have been fixed in later surveys. To minimize the consequences of errors in annual earnings, we exclude observations on weekly wages below $\$ 25$ or above $\$ 2,000$ (in 1988 dollars).

One possible consequence of the redesign was a fluctuation in rates of noninterviews for the supplement, which were low in the 1994 CPS and high in the 1995 CPS (personal communication from Greg Weyland, Bureau of the Census). This affects the data because supplement variables for people who do not respond are "allocated" by the Census Bureau. Another possible consequence of the redesign is a change in the type of people who report themselves as disabled or out of the labor force or both. To assess the impact of these phenomena, we used the March 1993-94 matched data. The March 1993 data were collected using the old CPS methodology. This allows us to restrict the sample for these two years to people who responded to the CPS supplement in 1993 (i.e., their responses were not allocated). We also report estimates with samples of individuals who identified themselves as disabled in both years or who answered the supplement questions on weeks worked in both years.

The analysis of matched data uses a sample aged 22-58 in both 1993 and 1994. We drop 21-year-olds because those aged 21 in 1994 were aged 20 in 1993, which is a group below our original lower age limit and a group for whom match rates are low. Similarly, we drop those over 58 in the 1994 data, so the age range and age distribution do not change between the two years (as was true for our cross-section analyses). For everyone in the matched sample, we have observations on disability status, data allocation, and SSA beneficiary status for both 1993 and 1994, so we can limit the sample to those with consistent responses across years.

Results of the matched-sample analysis are reported in table A1. The coefficient of interest is a 1994 dummy interacted with a dummy for being disabled. Results for a specification corresponding to table 2 and to a specification with a reduced set of covariates are reported. For women 21-39 and men 40-58, 
TABLE A1

Estimates in Matched Samples

Matched March 1993 to March 1994 Data

\begin{tabular}{|c|c|c|c|c|c|c|c|c|}
\hline & & \multicolumn{7}{|c|}{ Matched March 1993 to Мarch 1994 Data } \\
\hline & $\begin{array}{l}\text { FulL } \\
\text { SAMPLE } \\
(1)\end{array}$ & $\begin{array}{l}\text { All Matched } \\
\text { Records } \\
\text { (2) }\end{array}$ & $\begin{array}{c}\text { Same Disability } \\
\text { Status in } 1993 \\
\text { and } 1994 \\
(3)\end{array}$ & $\begin{array}{c}\text { Valid } \\
\text { Supplement } \\
\text { Response } \\
\text { in } 1993 \\
(4)\end{array}$ & $\begin{array}{c}\text { Valid } \\
\text { Supplement } \\
\text { Response } \\
\text { in } 1993 \\
\text { and } 1994 \\
(5)\end{array}$ & $\begin{array}{c}\text { Valid } \\
\text { Supplement } \\
\text { Response } \\
\text { and Same } \\
\text { Disability } \\
\text { in } 1993 \\
\text { and } 1994 \\
(6)\end{array}$ & $\begin{array}{c}\text { Col. } 6 \\
\text { Minus } \\
\text { Allocated Weeks } \\
\text { Worked } \\
\text { (7) }\end{array}$ & $\begin{array}{c}\text { Col. } 7 \text { and } \\
\text { Same SSA } \\
\text { Beneficiary Status } \\
\text { in } 1993 \\
\text { and } 1994 \\
(8)\end{array}$ \\
\hline & \multicolumn{8}{|c|}{ Men Aged 22-39 } \\
\hline Few covariates & $\begin{array}{c}-1.30 \\
(.97)\end{array}$ & $\begin{array}{c}-2.80 \\
(1.09)\end{array}$ & $\begin{array}{l}-.05 \\
(1.34)\end{array}$ & $\begin{array}{c}-3.21 \\
(1.12)\end{array}$ & $\begin{array}{c}-3.35 \\
(1.17)\end{array}$ & $\begin{array}{c}.13 \\
(1.40)\end{array}$ & $\begin{array}{l}-.71 \\
(1.41)\end{array}$ & $\begin{array}{c}-1.10 \\
(1.51)\end{array}$ \\
\hline Main specification & $\begin{array}{r}-1.29 \\
(.97)\end{array}$ & $\begin{array}{c}-2.76 \\
(1.09)\end{array}$ & $\begin{array}{l}-.20 \\
(1.35)\end{array}$ & $\begin{array}{c}-2.94 \\
(1.13)\end{array}$ & $\begin{array}{c}-3.10 \\
(1.17)\end{array}$ & $\begin{array}{c}.14 \\
(1.40)\end{array}$ & $\begin{array}{l}-.63 \\
(1.42)\end{array}$ & $\begin{array}{c}-1.09 \\
(1.51)\end{array}$ \\
\hline \multirow[t]{2}{*}{ Observations } & 18,435 & 12,967 & 12,396 & 11,828 & 11,027 & 10,599 & 10,450 & 10,349 \\
\hline & \multicolumn{8}{|c|}{ Women Aged 22-39 } \\
\hline Few covariates & $\begin{array}{c}-2.83 \\
(1.41)\end{array}$ & $\begin{array}{c}-1.02 \\
(1.69)\end{array}$ & $\begin{array}{c}-2.50 \\
(2.29)\end{array}$ & $\begin{array}{c}-1.63 \\
(1.76)\end{array}$ & $\begin{array}{c}-1.46 \\
(1.82)\end{array}$ & $\begin{array}{c}-2.47 \\
(2.34)\end{array}$ & $\begin{array}{c}-2.55 \\
(2.35)\end{array}$ & $\begin{array}{c}-3.00 \\
(2.54)\end{array}$ \\
\hline Main specification & $\begin{array}{c}-1.75 \\
(1.37)\end{array}$ & $\begin{array}{l}-.27 \\
(1.66)\end{array}$ & $\begin{array}{c}-1.87 \\
(2.25)\end{array}$ & $\begin{array}{c}-1.03 \\
(1.72)\end{array}$ & $\begin{array}{c}-1.10 \\
(1.78)\end{array}$ & $\begin{array}{c}-2.02 \\
(2.29)\end{array}$ & $\begin{array}{c}-2.08 \\
(2.31)\end{array}$ & $\begin{array}{c}-2.66 \\
(2.49)\end{array}$ \\
\hline Observations & 20,449 & 14,817 & 14,162 & 13,602 & 12,706 & 12,224 & 12,146 & 11,928 \\
\hline
\end{tabular}


Men Aged 40-58

\begin{tabular}{|c|c|c|c|c|c|c|c|c|}
\hline Few covariates & $\begin{array}{r}-3.75 \\
(.77)\end{array}$ & $\begin{array}{r}-3.64 \\
(.83)\end{array}$ & $\begin{array}{r}-3.40 \\
(.91)\end{array}$ & $\begin{array}{c}-4.21 \\
(.86)\end{array}$ & $\begin{array}{r}-3.72 \\
\quad(.88)\end{array}$ & $\begin{array}{r}-2.77 \\
(.93)\end{array}$ & $\begin{array}{r}-2.66 \\
(.93)\end{array}$ & $\begin{array}{r}-2.35 \\
\quad(.98)\end{array}$ \\
\hline Main specification & $\begin{array}{r}-3.91 \\
\quad .78)\end{array}$ & $\begin{array}{r}-3.74 \\
(.84)\end{array}$ & $\begin{array}{c}-3.52 \\
(.92)\end{array}$ & $\begin{array}{r}-4.38 \\
(.87)\end{array}$ & $\begin{array}{r}-3.82 \\
(.89)\end{array}$ & $\begin{array}{r}-2.76 \\
(.95)\end{array}$ & $\begin{array}{c}-2.69 \\
(.95)\end{array}$ & $\begin{array}{r}-2.40 \\
(.99)\end{array}$ \\
\hline Observations & 15,105 & 12,719 & 11,914 & 11,488 & 10,637 & 10,060 & 9,951 & 9,807 \\
\hline
\end{tabular}

NotE. - Standard errors are in parentheses. All entries are OLS estimates of coefficients on the disabled $\times 1994$ dummy in equations for weeks worked. Few covariates models include year, age group, race, and disabled main effects. Main specifications include the covariates from the few covariates specification, as well as the age group $\times$ year, race $\times$ year, education $\times$ year,
and region $\times$ year interactions. 
results under a variety of sample restrictions are remarkably consistent with the main set of cross-sectional results, though less precisely estimated. Estimates reported in column 8, from a sample restricted to those whose SSA beneficiary status was unchanged, also show similar effects. On the other hand, results for men aged 21-39 fluctuate considerably across columns; they are not always negative, and in some cases the negative estimates are much larger or smaller than the cross-sectional results in column 1 (these estimates are also sometimes sensitive to the use of sample weights). This variability is probably at least partially due to the fact that match rates are lower for this age group. Overall, however, table A1 suggests that the results in tables 2 and 3 are not misleading.

\section{March to April Matches for 1988-97}

March households in rotation groups 1-3 and 5-7 are eligible for interviewing in April. Observations to be matched were selected on the basis of rotation group, interview status, and age, as described for the March 1993-94 match. Revised Census Bureau confidentiality rules necessitated additional criteria for matching records in some years. We therefore matched households using the household identifier (H-IDNUM), person line number (A-LINENO), rotation group status (i.e., April H-MIS = March H-MIS plus one), and 1960 Census state code (HG-ST60). Of the eligible March records, 92.8 percent were successfully matched to an April record using these basic criteria (H-IDNUM, A-LINENO, H-MIS, and HG-ST60); 88.6 percent were successfully matched on both the basic criterion and sex and race, which is 95.4 percent of those matched using only basic criteria.

\section{E. EEOC Charge Statistics}

Charge rates used to construct the estimates in tables 5 and 6 are those marked with an ADA flag in the EEOC main charge record, part of a computerized database used to keep track of charge activity. We counted all charges flagged as ADA-related, including those originally filed with state FEP offices. We excluded records flagged as "hearing cases" related to government employees. Our counts of charges by state and year are very close, though not identical, to comparable data from EEOC reports. The EEOC reports note that charge data are periodically updated, and this seems likely to account for the discrepancy. The discussion of charge rates by age/sex group in the conclusion is based on our tabulation of charge statistics by age and sex. It should be noted, however, that age and sex variables for charging parties are missing or invalid for about 25 percent of the main charge records.

\section{F. Coding Pre-ADA State Disability Discrimination Provisions}

States were coded as having a strong preexisting FEP law if table 4-2 in Percy (1989) showed the state as having a law that covered discrimination by private employers on the basis of physical and mental disabilities and if these laws stipulated misdemeanor charges or civil penalties for discriminators as described on p. 43. Fifteen states fall into this category. A sixteenth state, Alaska, had a disability discrimination statute that did not cover mental illness for privatesector workers but was still coded as having a strong FEP law since the Alaska law included sanctions. 


\section{References}

Abram, Thomas G. "The Law, Its Interpretation, Levels of Enforcement Activity, and Effect on Employer Activity." A.E.R. Papers and Proc. 83 (May 1993): 62-66.

Acemoglu, Daron, and Angrist, Joshua D. "Consequences of Employment Protection? The Case of the Americans with Disabilities Act." Working Paper no. 6670. Cambridge, Mass.: NBER, July 1998.

Administrative Offices of U.S. Courts. Judicial Business of the United States Courts. http://www.uscourts.gov/judicial_business/contents.html, 1997.

Becker, Gary S. The Economics of Discrimination. 2d ed. Chicago: Univ. Chicago Press, 1971.

Bound, John. "The Health and Earnings of Rejected Disability Insurance Applicants." A.E.R. 79 (June 1989): 482-503.

. "Self-Reported versus Objective Measures of Health in Retirement Models." J. Human Resources 26 (Winter 1991): 106-38.

Bound, John, and Burkhauser, Richard V. "Economic Analysis of Transfer Programs Targeted on People with Disabilities." In The Handbook of Labor Economics, vol. 3, edited by Orley Ashenfelter and David Card. Amsterdam: NorthHolland, 1999.

Bound, John, and Waidmann, Timothy. "Disability Transfers, Self-Reported Health and the Labor Force Attachment of Older Men: Evidence from the Historical Record." Q.J.E. 107 (November 1992): 1393-1420.

Bureau of the Census. Current Population Survey, March 1988-91 on CD-ROM. Technical Documentation CPS-91-CD. Washington: Dept. Commerce, October 1991.

. Income, Poverty, and Valuation of Noncash Benefits: 1993. Current Population Reports, Consumer Income Series, Report no. P60-188. Washington: Dept. Commerce, 1994.

Burkhauser, Richard V., and Daly, Mary C. "Employment and Economic WellBeing Following the Onset of a Disability: The Role for Public Policy." In Disability, Work and Cash Benefits, edited by Jerry Mashaw et al. Kalamazoo, Mich.: Upjohn Inst., 1996.

Burkhauser, Richard V.; Haveman, Robert H.; and Wolfe, Barbara L. "How People with Disabilities Fare When Public Policies Change." J. Policy Analysis and Management 12 (Spring 1993): 251-69.

Clarke, Richard. "Employment Practices Liability Risks on the Rise." Nat. Un-

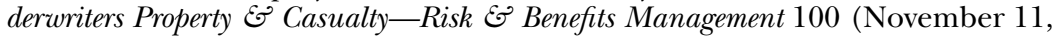
1996), p. 12.

Condon, David, and Zolna, Stan. "Stakes on the Rise of EPL Insurance." Nat. Underwriters Property $\mathcal{E}$ Casualty—Risk $\mathcal{E} \odot$ Benefits Management 101 (September 15, 1997).

DeLeire, Thomas. "The Unintended Consequences of the Americans with Disabilities Act." Regulation 23, no. 1 (2000): 21-24. (a)

_. "The Wage and Employment Effects of the Americans with Disabilities Act." J. Human Resources 35 (Fall 2000): 693-715. (b)

Dertouzos, James N. The End of Employment-at-Will: Legal and Economic Costs. Report no. P-7441. Santa Monica, Calif.: Rand Corp., May 1988.

Donahue, John J., III, and Siegelman, Peter. "The Changing Nature of Employment Discrimination Litigation.” Stanford Law Rev. 43 (May 1991): 9831033.

Dwyer, Debra S., and Mitchell, Olivia S. "Health Problems as Determinants of Retirement: Are Self-Rated Measures Endogenous?” Working Paper no. 6503. Cambridge, Mass.: NBER, April 1998. 
Epstein, Richard A. Forbidden Grounds: The Case against Employment Discrimination Laws. Cambridge, Mass.: Harvard Univ. Press, 1992.

Equal Employment Opportunity Commission. Technical Assistance Program. Disability Discrimination: Employment Discrimination Prohibited by the Americans with Disabilities Act of 1990. Washington: Government Printing Office, May 1995.

Hamermesh, Daniel S. "The Demand for Labor in the Long Run." In The Handbook of Labor Economics, vol. 1, edited by Orley Ashenfelter and Richard Layard. Amsterdam: North-Holland, 1986.

Job Accommodation Network. "Accommodation Benefit/Cost Data." Manuscript. Morgantown: West Virginia Univ., 1997.

Jovanovic, Boyan. "Job Matching and the Theory of Turnover." J.P.E. 87, no. 5, pt. 1 (October 1979): 972-90.

Kemp, Evan J., Jr. "Disability in Our Society: A Commentary." In Disability and Work: Incentives, Rights, and Opportunities, edited by Carolyn L. Weaver. Washington: American Enterprise Inst. Press, 1991.

Krueger, Alan B.; Kruse, Douglas; and Drastal, Susan. "Labor Market Effects of Spinal Cord Injuries in the Dawn of the Computer Age." Working Paper no. 5302. Cambridge, Mass.: NBER, October 1995.

Kubik, Jeffrey. "Incentives for the Identification and Treatment of Children with Disabilities: The Growth of the SSI Child Disability Program." Manuscript. Syracuse, N.Y.: Univ. Syracuse, Dept. Econ., September 1997.

Lazear, Edward P. "Job Security Provisions and Employment." Q.J.E. 105 (August 1990): 699-726.

Leonard, Jonathan S. "Disability Policy and the Return to Work." In Disability and Work: Incentives, Rights, and Opportunities, edited by Carolyn L. Weaver. Washington: American Enterprise Inst. Press, 1991.

Mortensen, Dale T. "Specific Capital and Labor Turnover." Bell J. Econ. 9 (Autumn 1978): 572-86.

Oi, Walter Y. "Disability and a Workfare-Welfare Dilemma." In Disability and Work: Incentives, Rights, and Opportunities, edited by Carolyn L. Weaver. Washington: American Enterprise Inst. Press, 1991.

Olson, Walter K. The Excuse Factory: How Employment Law Is Paralyzing the American Workplace. New York: Free Press, 1997.

Oyer, Paul, and Schaeffer, Scott. "Layoffs and Litigation." Manuscript. Evanston, Ill.: Northwestern Univ., Dept. Econ., 1998.

Parsons, Donald O. "The Decline in Male Labor Force Participation.” J.P.E. 88 (February 1980): 117-34.

Peracchi, Franco, and Welch, Finis. "How Representative Are Matched CrossSections? Evidence from the Current Population Survey." J. Econometrics 68 (July 1995): 153-79.

Percy, Stephen L. Disability Rights Mandates: Federal and State Compliance with Employment Protections and Architectural Barrier Removal. Report no. A-111. Washington: Advisory Comm. Intergovernmental Relations, April 1989.

Polivka, Anne E. "Data Watch: The Redesigned Current Population Survey." J. Econ. Perspectives 10 (Summer 1996): 169-80.

Poterba, James M., and Summers, Lawrence H. "Reporting Errors and Labor Market Dynamics." Econometrica 54 (November 1986): 1319-38.

Rosen, Sherwin. "Disability Accommodation and the Labor Market." In Disability and Work: Incentives, Rights, and Opportunities, edited by Carolyn L. Weaver. Washington: American Enterprise Inst. Press, 1991.

Scherer, Frederic M., and Ross, David. Industrial Market Structure and Economic Performance. 3d ed. Boston: Houghton Mifflin, 1990. 
Schmalensee, Richard. "Intra-industry Profitability Differences in U.S. Manufacturing, 1953-1983.” J. Indus. Econ. 37 (June 1989): 337-57.

Veres, John G., III, and Sims, Ronald R., eds. Human Resource Management and the Americans with Disabilities Act. Westport, Conn.: Quorum Books, 1995.

Weaver, Carolyn L. "Incentives versus Controls in Federal Disability Policy." In Disability and Work: Incentives, Rights, and Opportunities, edited by Carolyn L. Weaver. Washington: American Enterprise Inst. Press, 1991.

Weidenbaum, Murray. "How Government Reduces Employment." In Labor Markets, Employment Policy, and Job Creation, edited by Lewis C. Solmon and Alec R. Levenson. Boulder, Colo.: Westview, 1994.

Yelin, Edward H., and Katz, Patricia P. "Labor Force Trends of Persons with and without Disabilities.” Monthly Labor Rev. 117 (October 1994): 36-42. 